ENTREVISTA COM O PROFESSOR

Bianca Tavolari JOSÉ EDUARDO FARIA (Parte I)

Bianca Tavolari ${ }^{1}$, Celso Campilongo ${ }^{2}$, Fernando Rister ${ }^{3}$ e Orlando Villas Bôas Filho ${ }^{4}$ (Entrevistadores)

Nos dias 2 e 16 de dezembro do ano passado, o professor José Eduardo Faria nos recebeu na sala de sua casa, em duas manhãs de sábado, para conversar sobre sua trajetória acadêmica e profissional, sobre as referências que moldaram sua formação, bem como sobre a constituição da sociologia jurídica como campo de conhecimento. Também falamos sobre os rumos da sociologia jurídica já institucionalizada como disciplina e sobre tendências da pesquisa e do ensino em direito.

Todos aqueles que tiveram a oportunidade de ser alunos, orientandos ou, de alguma maneira, ouvir o professor Faria

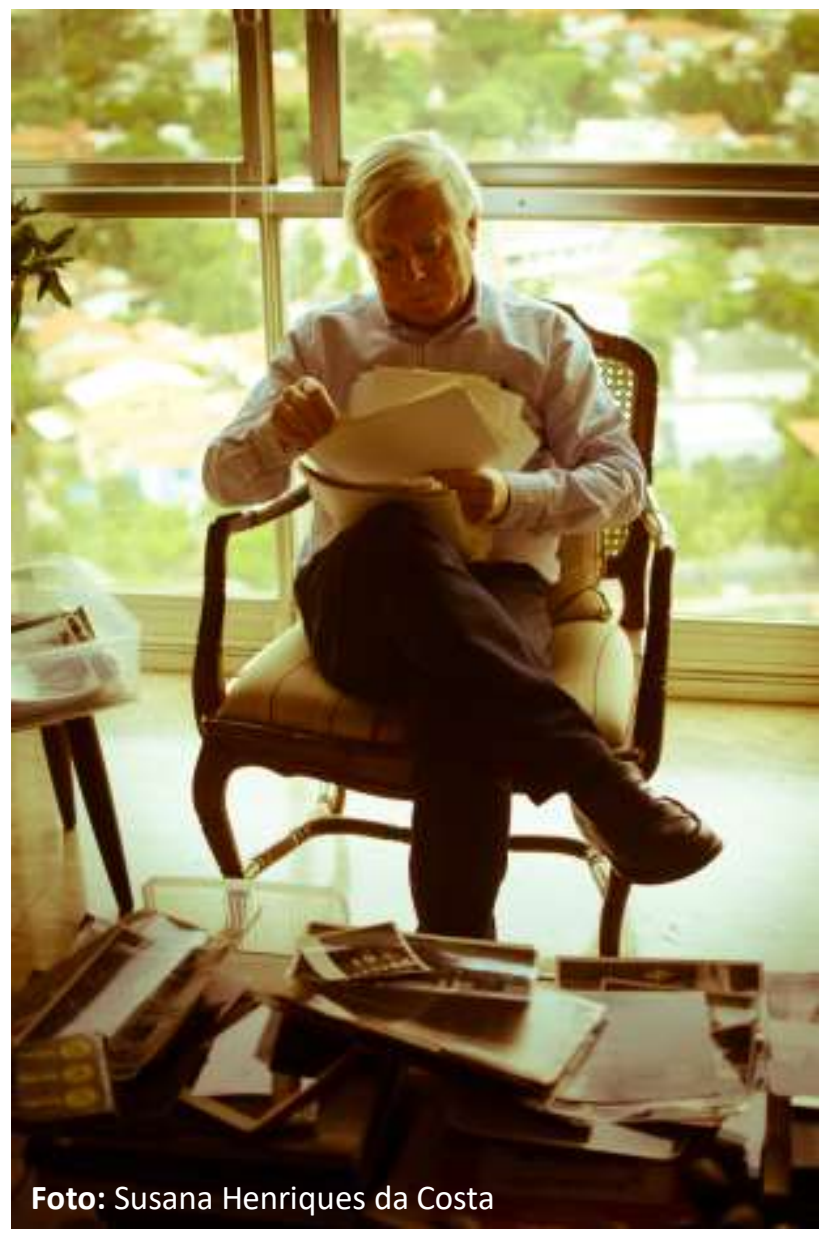
em aulas e palestras sabem que se trata de uma fala arguta, impressionantemente bem concatenada, ágil e repleta de detalhes. Nesta primeira parte da entrevista, o professor

\footnotetext{
${ }^{1}$ Doutoranda pela Universidade de São Paulo (USP).

${ }^{2}$ Livre Docente e Professor da Universidade de São Paulo (USP).

${ }^{3}$ Doutor e Professor da Universidade Presbiteriana Mackenzie (UPM).

${ }^{4}$ Doutor e Professor da Universidade de São Paulo (USP) e da Universidade Presbiteriana Mackenzie (UPM).
} 
Faria falou livremente sobre sua trajetória. Na segunda parte, que será publicada posteriormente, elaboramos questões específicas que foram previamente enviadas a ele. Em ambas as partes, o leitor encontrará uma narrativa potente, em primeira pessoa, de um dos principais intelectuais da área do direito no Brasil.

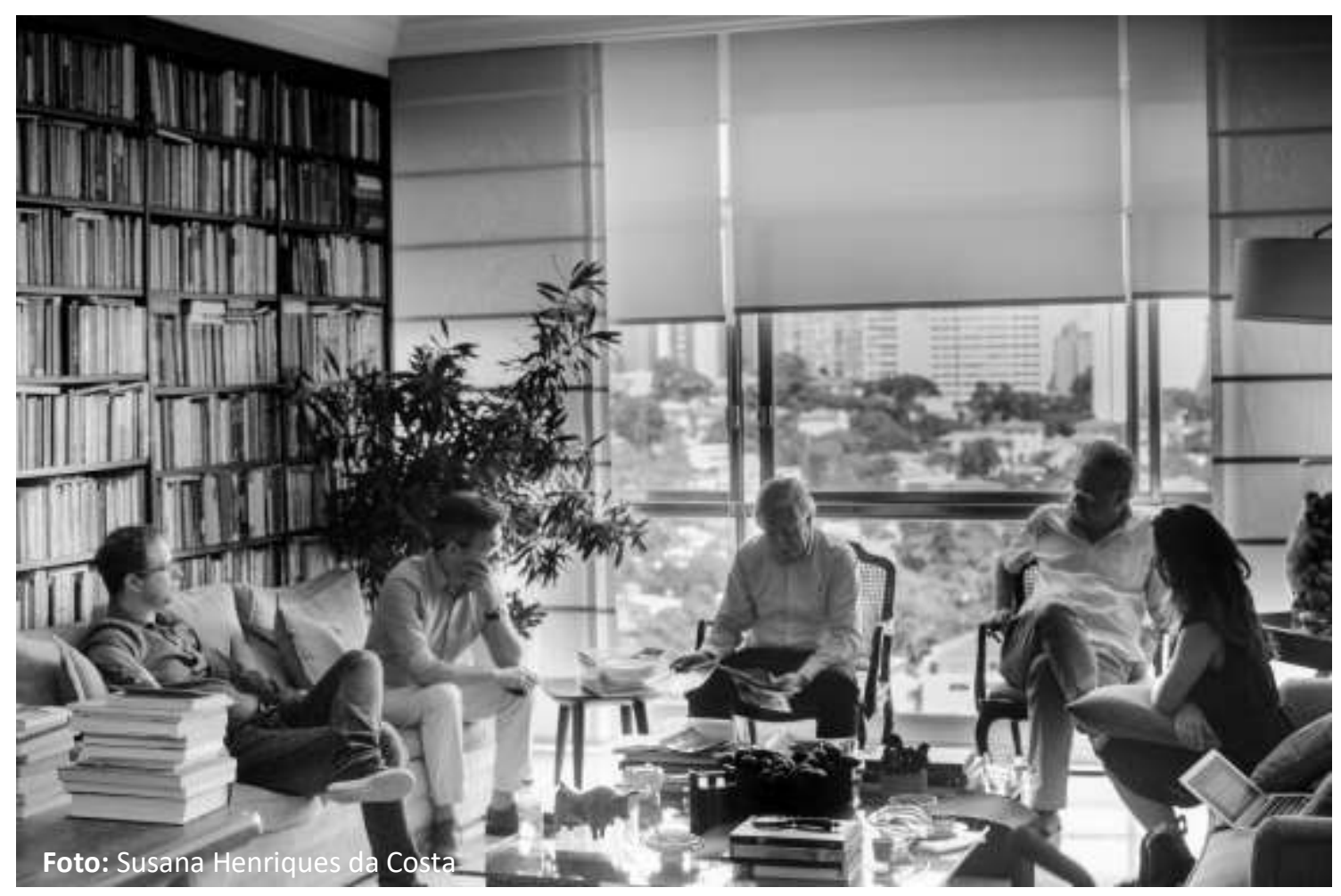

an

\section{PARTE I}

\section{ORIGENS}

Bom, se eu quiser fazer uma apresentação da minha carreira, acho que é importante lembrar que eu vim de uma família de professores universitários. E essa família de professores universitários se concentrou basicamente na área de ciências humanas. Essa opção - em primeiro lugar, pela carreira universitária e, segundo, pela área de ciências humanas - caracterizou, de certo modo, a passagem do século XIX para o século XX de várias famílias tradicionais brasileiras, de várias famílias tradicionais de São Paulo. 
Tanto por parte de pai como por parte de mãe, venho de famílias tradicionais que quebraram em função da crise de café. Quando essas famílias começaram a perceber que a falência era inexorável, alguns de seus líderes tiveram o bom senso de não dirigir seus filhos para os negócios, mas para a carreira universitária e para a universidade. Eu venho exatamente de famílias cujos líderes, percebendo a falência dos negócios familiares na área do café, acabaram induzindo seus respectivos filhos a fazer carreira universitária. Meu pai foi professor universitário, na Faculdade de Economia e Administração e na Faculdade de Direito da USP. Graduada por esta instituição e com doutorado obtido na Universidade de Paris I, a irmã de meu pai foi professora universitária, primeiramente em Bordeaux, depois professora titular na Unesp. Meu tio foi professor catedrático de direito processual civil na USP, tendo chegado a diretor da Faculdade de Direito e ocupado a reitoria, durante certo período. Um dos primos de minha mãe foi pesquisador do CEBRAP (Centro Brasileiro de Análise e Planejamento), nos primórdios da entidade.

Para vocês terem uma ideia do que é esse processo de mobilidade social descendente, no meu lado materno, meu bisavô chegou a ter nove filhos. Desses nove, o primeiro foi um empresário bem sucedido. Médico, foi um homem rico, sócio de empresas e de uma casa bancária em Campinas. Na outra ponta dessa linha familiar, o filho menor do meu bisavô era bedel de um grupo escolar na cidade de Amparo. Quer dizer, o mais velho era formado na Europa, quatro ou cinco eram formados na USP e os últimos eram semialfabetizados. Meu avô foi da área intermediária. Formou-se em medicina na USP e se tornou um médico sanitarista importante na geração dele, dirigindo programas da Organização Mundial da Saúde e da Organização Pan-americana de Saúde para toda a América Latina na área de profilaxia da lepra e da tuberculose, o que o tornou, de algum modo, envolvido em atividades conjuntas com a USP. De alguma maneira, isso tudo acabou fazendo com que, desde cedo, eu vivesse, tanto em casa quanto no universo familiar integrado por tios e primos, num ambiente basicamente universitário. Meu pai, 
por exemplo, começou a carreira universitária bem cedo. Logo depois de formado no Largo de São Francisco, fez uma segunda faculdade, de jornalismo. Formou-se na primeira turma da Cásper Líbero, tornou-se professor da escola e, em seguida, assumiu a coordenação do curso. Também pertenceu à primeira geração de professores da Faculdade de Economia e Administração, antiga Faculdade de Ciências Econômicas e Administrativas, que no início funcionou na rua Doutor Vila Nova, travessa da Rua Maria Antônia. Situados nessa rua, hoje icônica, a Faculdade de Filosofia e o prédio da Faculdade de Ciências Econômicas se comunicavam internamente.

O interessante é que esse ambiente universitário acabou trazendo, para dentro de minha casa, o relacionamento entre grupos de docentes. Mensalmente, aos domingos, havia almoços com alguns professores da FEA e do Largo de São Francisco. Isso fez com que, a partir da adolescência, eu passasse a acompanhar as discussões e acabasse estabelecendo uma relação com alguns desses professores. Tinha ainda uma segunda característica: costumo brincar dizendo que eu entrei na faculdade com seis anos. Era o filho mais velho de cinco irmãos e não havia quem pudesse tomar conta de mim. Quando ia dar aula, meu pai me levava junto e eu ficava na sala dele ou, então, eu ficava na própria sala de aula, enquanto ele lecionava. Fazia minha lição de casa e andava pelo prédio da FEA.

Há algo importante a ser destacado. Na época a que estou me referindo, havia uma distância social entre o alunado da São Francisco e da FEA. Enquanto o Largo de São Francisco atraía alunos de classe média alta e da alta burguesia - quando estudei lá a maior parte dos meus colegas vinha de famílias tradicionais, cujos avós eram nomes de viadutos, estradas e pontes -, os alunos da FEA eram de origem italiana, judaica ou asiática. Ou seja, vinham de um extrato social muito baixo. E tinham uma noção da necessidade de se refinar, em todos os sentidos. Um dos refinamentos que buscaram foi no campo da música clássica. Como meu pai tinha um fascínio por música clássica e ouvia o dia inteiro, acabou sendo convidado pelo Centro Acadêmico Visconde de Cairú a dar a 
cursos sobre música clássica aos sábados à tarde. Ele morava numa casa perto do Horto Florestal, onde ficava estudando de manhã, ouvindo música no mais alto volume. Durante três anos, ele deu os cursos pedidos pelo Centro Acadêmico, frequentados por essa geração de estudantes de economia e administração vindos de famílias de imigrantes pobres. Essa é a geração que acabou sendo integrada por Affonso Celso Pastore, Miguel Colasuonno, Carlos Antônio Roca, ou seja, pelo pessoal que iria compor o grupo do [Antônio] Delfim [Netto], um dos dois grandes líderes intelectuais da escola - o outro era o Luis de Freitas Bueno, engenheiro que ensinava estatística. De alguma maneira, tudo isso acabou fazendo com que eu também viesse a assistir a essas aulas, com que acabasse frequentando aquele ambiente quando ainda estava cursando o ginásio. Digo para meus alunos que, durante os anos da minha infância e juventude, o prédio da FEA na Doutor Vila Nova, no coração da Vila Buarque, foi um dos meus dois quintais.

Fora isso, meu pai tinha aquela casa próxima ao Horto, de que falei. Era o outro quintal. A casa tinha uns três mil metros quadrados e uma história trágica. Havia pertencido à família de um ex-ministro da Fazenda, cujo neto morreu afogado na piscina. Diante da tragédia, a família vendeu a casa e meu pai a comprou a um preço mais barato, porém com a condição imposta por minha mãe de que a piscina fosse soterrada. Condição aceita, nela foi plantado um abacateiro que se revelou altamente produtivo - durante muitos anos comíamos abacate no café da manhã e nas demais refeições. Era a primeira coisa que fazia quando ainda era ginasiano, assim que chegava da FEA.

Mas, retomando, a casa era enorme e tinha duas bibliotecas. De tanto permanecer nelas, elas formaram meu quintal intelectual. Desde o início, como a região era longe tudo, as ruas não eram asfaltadas e não havia iluminação pública, eu passava meus dias inteiros lendo naquelas bibliotecas, descobrindo um monte de coisas. Primeiro, meu pai assinava o Times e, graças a isso, comecei a ler em inglês. Depois disso, minha tia Maria Alice, que era 
professora da universidade de Bordeaux, mandava coisas em francês para mim. Pelos livros e revistas que enviava, comecei a ler francês. E, assim, fui descobrindo o mundo.

A biblioteca pertencia a um professor universitário nascido na década de 1920 e que pertenceu a uma geração que foi para a guerra, na Itália, e combateu o varguismo. Refirome à geração que nasceu sob a égide do antigo Partido Democrático, mais tarde convertida na União Democrática Nacional. Minha família pertenceu aos dois partidos um de meus avós chegou a presidir o diretório municipal da primeira agremiação. A geração de meu pai é a que foi convocada para lutar na Itália. Meu pai foi convocado, mas, por problemas de vista, permaneceu como tenente e instrutor num quartel de Lorena experiência que, a meu ver, fez dele um chefe de família autoritário, como se liderasse um batalhão de cinco filhos. Com o fim da guerra, a geração dele acabou sendo fortemente impactada por alguns ideais, principalmente os da Democracia Cristã. Os líderes intelectuais dessa geração eram o Alceu Amoroso Lima, no Rio de Janeiro, e uma figura que hoje é muito pouco conhecida, o Antônio Queiroz Filho. O Alceu tinha muita visibilidade e, na época, o Rio era a capital do país. O Queiroz Filho era menos conhecido. Foi promotor público, procurador de justiça, fundador do Partido Democrata Cristão, deputado federal e presidente da Caixa Econômica. Foi indicado para ser embaixador do Brasil na lugoslávia, mas acabou sendo vetado pelo Senado, que fazia oposição ao presidente João Goulart. No pré-64, para tentar desgastar Goulart, a direita parlamentar sacrificou o Queiroz Filho, que morreu pouco tempo depois, de depressão e desgosto.

A geração a que me refiro foi fortemente influenciada por dois grandes pensadores católicos: um inglês, chamado Gilbert Keith Chesterton, e um francês, chamado Jacques Maritain. Com uma formação tomista e moralista, tanto Maritain quanto Chesterton eram católicos conservadores que tentavam oxigenar um catolicismo empedernido e tentaram repensar questões sociais e filosóficas num mundo então marcado pelos extremismos e radicalismos totalitários. Uma das questões sociais tratava dos embates sindicais, questão essa que já havia sido abordada no final do século XIX pela encíclica Rerum Novarum, do 
Papa Leão XIII. Influenciada por Chesterton e Maritain, a geração de meu pai é a que pertencem, entre outros, o Plínio de Arruda Sampaio, o Queiroz Filho, o [André Franco] Montoro, o Paulo Tarso Santos, o Chopin Tavares de Lima, o Teóphilo Ribeiro de Andrade. Bem jovens, eles serviram ao governo Carvalho Pinto, introduzindo estratégias de planejamento na administração pública estadual e aperfeiçoando os modos de financiamento de políticas públicas. Alguns deles foram para fora do país para fazer seus doutorados, enquanto outros, ficando aqui, passaram a convidar pensadores e intelectuais europeus para virem ao Brasil. Um desses foi o arquiteto, urbanista e padre dominicano Louis Joseph Lebret. Hoje pouco lembrado, ele foi uma figura importante, que ofereceu uma visão humanista para o planejamento urbano e promoveu discussões que alimentaram gestões de prefeitos marcantes, como as de Prestes Maia e Olavo Setúbal.

Daquela geração, cujos integrantes vi passar em casa ou estive na casa deles, vários foram para a política. O Montoro chegou a senador, ministro e governador. O Queiroz, o Paulo de Tarso, o Plínio de Arruda Sampaio e o Chopin Tavares de Lima viraram deputados. Em chapa articulada pelo Montoro, meu pai chegou a ser candidato à Câmara Municipal, tendo ficado na suplência. Quando foi a vez de assumir, desistiu, porque vinha priorizando a carreira acadêmica e escrevendo livros com algum sucesso à época, um dos quais acabou sendo publicado pela editora Agir, do Alceu Amoroso Lima, com que se dava bem graças à intermediação do Queiroz Filho. O doutor Queiroz, como o chamávamos, tinha uma casa em Campos do Jordão, onde um tio meu e meu avô também tinham propriedades. Nos meses de férias, havia um seminário organizado pelo Queiroz para jovens de 16 a 18 anos, nos quais se discutia filosofia, política e temas do momento. Como eu subia para passar as férias de janeiro e julho em Campos, acabei sendo integrado àquele grupo. Mas essa experiência começa a ser posta em xeque com a ascensão do Papa João XXIII e das subsequentes convocações de conferências episcopais de bispos de todo o mundo, com base no Concílio Vaticano II, por meio da bula papal Humanae Salutis - acho que era esse o 
título, se não me falha a memória. Foram documentos destinados a modernizar a Igreja e que tentaram introduzir uma visão nova, menos conservadora e mais crítica, das questões sociais. Esses documentos exerceram um impacto brutal na geração a que me refiro. Aqueles que até então discutiam políticas públicas e questões sociais a partir do catolicismo e moralismo de Chesterton e da ortodoxia católica de Maritain acabaram se dividindo. Uma parte começou a levantar questões sobre pobreza, sobre luta de classes e transferência de renda, seguindo a nova bula do Vaticano. Em termos simplistas, priorizando a metafísica e desprezando questões mais terrenas, a outra parte se fechou na ortodoxia e no conservadorismo, menosprezando discussões sobre justiça, reforma social e libertação das diferentes formas de opressão. Além disso, as divergências foram agravadas pela Guerra Fria, provocando fortes embates ideológicos em meio àquela geração. Esses embates levaram ao rompimento de relações pessoais, principalmente após o golpe de 1964. A partir da fratura, alguns foram para a esquerda, enquanto outros continuaram com suas convicções ortodoxas, sendo com isso deslocados para a direita. Meu pai ficou no grupo mais conservador, enquanto seus colegas de governo Carvalho Pinto e do Partido Democrata Cristão converteram-se em progressistas.

Em frente à minha casa, morava a irmã da minha mãe, cujo marido pertencia a uma família tradicional. Era filho de um deputado da UDN e, também formado pelo Largo São Francisco, ficou na posição à esquerda, tendo se auto-exilado após 1964. Antigo estudante da Universidade Patrice Lumumba, em Moscou, formou uma biblioteca belíssima, de forte viés marxista. Apesar da falta de diálogo entre os cunhados, para mim bastava atravessar a rua para mudar o frame ideológico das minhas fontes de livros. Se o acervo das bibliotecas de meu pai tinha sofrido condicionamento de autores como Maritain e Chesterton, o acervo de meu tio era uma festa. Tinha livros que iam de Caio Prado Jr., [Alberto] Guerreiro Ramos, Álvaro Vieira Pinto, Celso Furtado, Roland Corbisier a Antonio Gramsci, Althusser e por aí vai.

\section{PRIMEIRAS DISSIDÊNCIAS}


Apesar de nada me impedir de atravessar a rua, as divergências ideológicas familiares me traumatizaram. Além disso, esse meu tio tinha certa vinculação com alguns dominicanos - não nos esqueçamos que a ordem exerceu um papel político importante na época da ditadura. Independentemente do trauma, dos catorze ou quinze aos dezessete ou dezoito anos, fiquei submerso em duas bibliotecas absolutamente opostas do ponto de vista ideológico, lendo de forma compulsiva.

Fora isso, aconteceram algumas coisas interessantes para mim. Uma delas é que meu pai, quando fez a Cásper Líbero, além de ser procurador do Estado, professor da FEA e, depois, do Largo de São Francisco, acabou se tornando articulista e colunista do antigo jornal A Gazeta, além de professor do curso de jornalismo. E, com isso, eu acabei frequentando a redação, no auge do jornal, e a rádio Gazeta. Aquele mundo, no qual ingressei desse modo fortuito, me fascinou. Quando ingresso na adolescência, morava, como já disse, numa casa situada numa área isolada. Eram antigas chácaras de alemães. A comunicação com o resto da cidade de São Paulo obrigatoriamente se afunilava na ponte das Bandeiras e na ponte do Pacaembu. Por falta de acesso viável ao centro, aquela área era bem suburbana. Era como se eu morasse numa cidade do interior e meu pai não tinha nenhuma vontade de permitir que eu estudasse em colégios mais à altura de uma família tradicional. Meus avós já moravam em Higienópolis e tinham um padrão de vida que lhes permitia morar num prédio sofisticado. Em outras palavras, acabei estudando em colégio público no momento em que começava um forte processo de repressão depois de 1964 . 0 governo estadual começou a demitir professores considerados de esquerda ou a concentrá-los em algumas poucas unidades, como nos chamados colégios chamados vocacionais, dos quais o mais conhecido era o Oswaldo Aranha, em Santo Amaro. O menos conhecido, que não tinha título de colégio vocacional, é aquele no qual estudei, o Colégio Estadual Octavio Mendes, mais conhecido como Cedom. 
Octavio Mendes, sogro de um político que chegou ao governo estadual, era um professor de direito comercial, da Faculdade de Direito da USP. O corpo docente do Cedom tinha antigos professores, sérios e competentes, e uma geração de docentes que faziam licenciatura na Faculdade de Filosofia, Letras e Ciências Humanas da USP. Informalmente, eles converteram o Cedom numa espécie de plano B do antigo Colégio de Aplicação. Tive a sorte de ser aluno dessa geração de professores confinados no Cedom por razões ideológicas. Eles me abriram o mundo, consolidaram as leituras mais abertas e críticas, despertaram minha sensibilidade para novos temas e refinaram as leituras que vinha fazendo na biblioteca do meu tio, à revelia de meu pai. Além disso, o Cedom conseguiu reunir, à época, um grupo de alunos muito bem preparados. Para ingressar na escola tivemos de fazer o chamado exame de admissão, que era uma espécie de vestibular. No ensino médio do curso científico, destinado às ciências exatas e biomédicas, alguns colegas viriam a ser, no futuro, conhecidos médicos e engenheiros. Do curso clássico, destinado à área de ciências humanas, meu colega de classe e que se sentava ao meu lado, Modesto Florenzano, seria professor titular de História e vice-diretor da Faculdade de Filosofia da USP. Duas ou três séries atrás, estava o Sérgio Adorno, de cuja banca de livre-docência participei, e que hoje é titular do Departamento de Ciências Sociais e ex-diretor da Faculdade.

O fascínio por algumas matérias me levou a me aproximar de três ou quatro professores. Um ensinava história: Vivaldo Flores. Ele foi decisivo porque, além de ser um excelente professor da matéria, oferecia um curso de história da arte e música aos sábados. Outra ensinava francês. Era uma jovem portuguesa, de uma família antisalazarista exilada em Paris. Foi alfabetizada em francês e depois, por questão de sobrevivência, veio para São Paulo, tornando-se docente da rede pública. Era uma mulher de esquerda, chamada Maria do Céu Lopes de Souza. Um dia ela me chamou, elogiou-me como um dos bons alunos da turma, recomendou que eu melhorasse a pronúncia e foi clara ao sugerir que eu deveria sair do bairro e ir para cidade ver coisas novas. Ela me 
estimulou a escrever, o que me levou, aos quinze ou dezesseis anos, a escrever uns continhos. Tenho até vergonha de dizer isso, eram textos medíocres. Mas acontece que ela gostou de um deles e, um dia, me chama e pergunta o que eu faria aquela noite. Tomei um susto, pois ela era bonita, tinha quase 40 anos e havia se casado com um homem bem mais moço. Passadas a estupefação e a hesitação, ela deixou claro que o convite era para conhecer a redação da Folha de S. Paulo. Meu pequeno texto não ganharia o prêmio, mas fora classificado para publicação e era isso que importava. Conhecer a redação era uma forma de me estimular a seguir aquele caminho. Depois, ela me chamou, junto com mais outros dez alunos, e começou a dizer: "vocês tem vocação para teatro". E passou a nos estimular a ir ao Teatro de Arena, que fica até hoje ali na rotunda, no começo da Consolação. Por fim, começou a trazer uma série de textos de literatura francesa para lermos, principalmente Sartre e Camus. Ou seja, ela nos descortinou a noite, quando assistimos ao fechamento de uma das edições da Folha, quando passamos a frequentar teatro e quando passamos a escrever cada vez mais. Tudo isso acabou me levando a optar pela área de ciências humanas.

Minha primeira opção de carreira não foi direito, mas arquitetura e urbanismo. Mas acabei desestimulado, por ter problema de controle motor nas mãos, o que me atrapalharia de algum modo. A outra alternativa foi a área de direito. Essa foi uma fase de transição da adolescência, em que vivi uma espécie de tragédia familiar. No final do ginásio, eu era um dos melhores alunos da classe e, para surpresa da minha família, fui reprovado e perdi um ano. Fui reprovado por 0,5 ponto em biologia e álgebra, apesar das excelentes notas em português, história e geografia. Foi a primeira vez que isso aconteceu no meu núcleo familiar. Lembro que meu pai deixou de falar comigo, minha mãe mudou a forma de tratamento e alguns irmãos passaram a me ver como um ser inferior ou erva daninha da família. Mas, quando comecei a refazer as matérias, os professores de humanas, com quem me dava muito bem, falaram: "concentre-se em biologia $e$ 
matemática; mas nas outras matérias você será aprovado". Com isso, alguns desses professores me fizeram atuar como uma espécie de monitor, experiência da qual gostei e que abriu caminho para o que eu queria. É paradoxal: fui gostando ainda mais do colégio do ponto de vista da atividade escolar e comecei a passar mais tempo do que devia ali. Entrava de manhã, já que eu morava muito próximo do colégio. Almoçava em casa e voltava para lá para ajudar os professores, nadar e jogar basquete. Era um momento de descoberta do mundo, de testosterona à flor da pele, aquela coisa toda. Com isso, constatei a falta de foco de meus pais. Meu avô materno, o médico sanitarista que era meu único interlocutor, sugeriu que eu fizesse mais esporte para suportar as pressões familiares por causa da reprovação. Foi o que me levou a me tornar atleta das categorias inferiores do Clube Espéria. Além de ficar na escola e em bibliotecas familiares, virei jogador de basquete. Apesar de ser baixo, fui vice-campeão paulista nas divisões infantil e juvenil.

E aí, justamente, acontece outra coisa importante. Naquele momento, o governo do Estado de São Paulo concedeu um professor de teatro a cada colégio vocacional. 0 professor de teatro que foi indicado para o Cedom era o Afonso Gentil. Era um período em que eu tinha disponibilidade tempo, por causa da obrigatoriedade de refazer um ano perdido. Afonso Gentil era nada mais nada menos do que um dos diretores do Teatro de Arena. Era um sujeito vinculado ao Gianfrancesco Guarnieri e eu fui um dos primeiros alunos do Cedom a me matricular no curso dele. Um dia me chamou e disse: "eu estou precisando de um auxiliar, de alguém aqui, porque venho do centro da cidade, que fica longe". E, assim, eu me tornei uma espécie de assistente administrativo dele. Com o tempo, ele me estimulou a ler e a me enfronhar na assistência de direção. Fizemos algumas peças no Teatro do Cedom, que tiveram um impacto brutal em minha vida. Era um teatro engajado, numa espécie de dramaturgia dos oprimidos. Uma peça de Brecht, intitulada $O$ processo de Lucullus. Outra peça foi de Antônio Calado, intitulada Forró no Engenho Cananeia. Evidentemente, minha família se recusou a ver as peças e, pior, passou 
a me pressionar para que deixasse o grupo de teatro, que foi mais uma de minhas descobertas e me levou a amar o ensino médio. Naquele momento, com a industrialização brasileira, $90 \%$ dos meninos iam para o curso científico e $90 \%$ das meninas iam para o curso clássico. Graças a professores de história, francês e teatro, graças ao técnico de basquete do Espéria, Pedro Genevicius, que era bastante compreensivo e que chegou à seleção brasileira, graças ao Gentil e graças à classe em que Modesto e eu éramos os únicos alunos, eu me vi em meio a uma turma feminina. Foi uma experiência ímpar.

Com isso tudo, ampliei meu gosto pela análise política, pela observação dos acontecimentos. Discutia-se muito sobre política na minha casa, como já disse. Alguns políticos também frequentavam minha casa. Tive um tio que foi vereador pela UDN e líder da oposição na Câmara Municipal. Se optar pela área do direito no vestibular se tornou inexorável, o gosto pela análise política e por temas abstratos, despertado no ensino médio, deixou claro para mim que eu não seria um operador do direito e que não trabalharia com meu pai, por absoluta incompatibilidade de gênio e ideologia. Não queria repetir a carreira dele, que havia começado trabalhando com meu tio, diretor da Faculdade de Direito, num escritório em sociedade com um profissional que mais tarde viria a ser chefe da Casa Civil da Presidência da República. Na fase final do ensino médio, meus contatos de Campos do Jordão foram decisivos. Era o jornalismo que me encantava. Ou, quem sabe, a carreira acadêmica - e isso sem sequer ter prestado ainda vestibular. Tinha 17 anos quando descobri que um dos melhores amigos do meu tio era José Maria Homem de Montes, o principal executivo do jornal O Estado de São Paulo e braço direito de Júlio de Mesquita Filho. Também conhecido nas redações como "Deus", o doutor Julinho era dono do Estadão, que, na época, era quatro ou cinco vezes maior do que o grupo Globo. Num almoço de fim de ano, vendo meu tio e o Montes jogando conversa fora, encostei nele, pedi para conhecer a redação do Estadão e disse que queria ser jornalista. Ele olhou para mim. O olhar dizia que ele tinha me achado petulante. Disse, 
friamente, o seguinte: "vai ter uma bolsa da qual o jornal é patrocinador e que levará um grupo pra estudar nos Estados Unidos. Candidate-se. Se você se candidatar, vamos ver o que acontece". Eu me candidatei e, para minha surpresa, ganhei a bolsa após uma bateria de entrevistas. O projeto era passar um ano no Miami Herald, um importante jornal da Flórida. O processo seletivo foi excessivamente duro porque o Montes queria mostrar sua imparcialidade. Mas meu pai sabia que, se fosse fazer o estágio em Miami, eu não faria o vestibular e perderia mais um ano letivo. Ele me proibiu de viajar, não me dando autorização, já que eu não tinha completado 18 anos ainda. Isso contribuiu para esgarçar ainda mais nossas relações.

\section{A ENTRADA NO JORNALISMO}

Assim, acabei fazendo o vestibular em direito na USP, em novembro de 1967, e fui aprovado. O Montes, ainda chateado por eu não ter ido para o estágio no Miami Herald, me chamou de lado em dezembro e disse: "tudo bem, foi ordem paterna, mas como você fará 18 anos em breve há outra possibilidade de trabalho". E aí contou que, o vespertino da empresa, um jornal criativo e fantástico lançado há um ano, mas que não gerava lucro, precisava contratar jornalistas. Era o Jornal da Tarde, que tinha sido criado em 1967. Segundo ele, a Abril havia convidado o diretor do JT, Mino Carta, para criar a Veja, que tinha levado um número significativo de editores, sub-editores, copidesques e repórteres com ele. Do dia para a noite, ficou um vácuo no Jornal da Tarde. Esse jornal fez, no jornalismo do final dos anos 1960, uma revolução tão impactante quanto a do Jornal do Brasil, nos anos 1950. "Não temos repórteres. Quer começar fazendo reportagens?" Tomei um susto, mas aceitei, é claro. O convite era para um cargo maior do que almejava. E comecei a trabalhar meses antes do início do primeiro semestre letivo de 1968.

Fui treinado durante semanas e minha primeira tarefa foi cobrir uma gravação de novela da Globo, com a Rosamaria Murtinho e com o Armando Bógus. Era uma novela de época no Horto Florestal. Depois de ter rodado um pouco pelas áreas de polícia, temas 
gerais e economia, veio a crise estudantil de 1968, iniciada em Paris e que teve ecos pelo mundo inteiro, inclusive em São Paulo. O JT criou uma subeditoria específica para esta área e virei repórter de assuntos estudantis. Eu, que não tinha nem mesmo quarenta dias de aula como universitário. Era tudo o que queria. Primeiro, porque como repórter estudantil, eu não precisava frequentar o jornal. Só passava lá para escrever matérias. Então, cursava a Faculdade de Direito e ia para a Faculdade de Filosofia, na rua Maria Antonia, que era o centro dos acontecimentos. Retomei o convívio com antigos colegas de ensino médio que se tornaram líderes do movimento estudantil e frequentava a FEA, onde meu pai tinha sala. Sempre como repórter, assisti a várias negociações e até dei palpites em algumas. O presidente da UEE [União Estadual dos Estudantes] era o José Dirceu e o da UNE [União Nacional dos Estudantes], Luís Travassos. O presidente do Centro Acadêmico XI de Agosto, que liderou a ocupação da Faculdade de Direito, era o Marco Aurélio Ribeiro. Em alguns momentos, eu mesmo já não sabia quais eram os limites de minha atuação profissional naquele clima.

Minhas reportagens publicadas pelo JT começaram a crescer em espaço. Acabei cobrindo o quebra-quebra da sede do Citibank, na avenida Ipiranga, o confronto entre a Faculdade de Filosofia e a turma do CCC [Comando de Caça aos Comunistas] do Mackenzie, a desocupação da Faculdade de Direito e o Congresso da UNE, em Ibiúna. Com apenas 18 anos, descobri que finalmente havia conseguido ultrapassar os limites de um universo fechado em bibliotecas da família. No meio disso tudo, vem o Al-5 e o aumento da opressão da ditadura, inclusive com censura de imprensa. E, como o jornal tinha fundido as editorias de economia e política numa só editoria chamada "nacional", fui transferido para ela com o refluxo do movimento estudantil. $O$ editor fechador era o Guilherme Duncan, jornalista carioca que, anos depois, seria o executivo do Prêmio Esso, o mais importante da área de jornalismo. O editor de conteúdo e pauteiro se chamava Rolf Kunz. Já formado em filosofia, cursando uma pós lato sensu na FGV, ele estava terminando 
seu mestrado na USP com uma dissertação sobre Rousseau, orientado pela Maria Sylvia de Carvalho Franco, e planejando seu doutorado sobre Quesnay, que teria a orientação do João Paulo Monteiro. Entre os demais integrantes da equipe estavam Fernando Morais, mais tarde biógrafo de Assis Chateaubriand, deputado estadual e secretário de educação; Miguel Jorge, que seria vice-presidente da Volkswagen e ministro da indústria e comércio do segundo mandato de Lula; Ricardo Setti, que seria editor-chefe do Estadão e da Playboy; e João Victor Strauss e Carlos Brickmann. Foi um período incrível, de muito trabalho e muita aprendizagem. O ambiente do $J T$, um jornal pequeno e leve, porém criativo, era cosmopolita, por ter atraído jovens jornalistas do país inteiro, principalmente de Belo Horizonte e Juiz de Fora.

Eu, que era o mais moço de todos e o mais inexperiente, passei a ter ao meu lado, na redação, escrevendo nas velhas máquinas Lexington 80 , da Olivetti, um contista como Luiz Vilela; o crítico teatral Sábato Magaldi, que mais tarde entraria para a Academia Brasileira de Letras; o maestro Diogo Pacheco, crítico musical; Leo Gilson Ribeiro, crítico literário; Paulo Cotrim, crítico de restaurantes; Fernando Mitre, hoje diretor da TV Band; e Flávio Márcio, jovem teatrólogo, falecido muito cedo, que teve uma de suas peças chamada Réveillon - encenada no Teatro Municipal. Havia vários outros jornalistas importantes naquele grupo, com os quais aprendi muito. O JT funcionava no charmoso prédio da rua Major Quedinho, quase em frente à biblioteca [Mário de Andrade]. No térreo, tinha um dos melhores American bar da cidade e um auditório bem montado. $\mathrm{O}$ jornal ocupava do 1ㅇ ao 7o andar e, daí para cima, era um hotel, um dos melhores da época, o Jaraguá, que tinha sido construído pela família Mesquita. Como os elevadores do jornal eram insuficientes para atender à demanda, vários jornalistas - eu entre eles optavam por subir pelo elevador do prédio ao lado, onde funcionava a Rádio Eldorado. A ligação dos prédios se dava por meio de um corredor estreito e mínimo, com o tráfego prejudicado por um sofá caindo aos pedaços, onde costumava dormir, depois do almoço, um tal de João Rubinato, mais conhecido como Adoniran Barbosa. A gente saltava por 
cima dele, simplesmente. O hotel Jaraguá era o melhor da cidade e o bar era frequentado pelos jornalistas mais bem pagos, pela família Mesquita, por hóspedes e por empresários. A área era fantástica. O prédio estava a uns 200 metros do Paribar, ao lado da biblioteca Mário de Andrade, em frente aos restaurantes Paddock e Bistrô, próximo das principais livrarias - como a Zahar, a Livraria Francesa, a Agir, Mestre Jou, Duas Cidades e Brasiliense -, do Teatro Municipal e da sede de entidades empresariais e de sindicatos. Como repórter da editoria nacional, deixei de conviver com o movimento estudantil, então dizimado, e passei a cobrir economia, o que me obrigou a entrevistar empresários, secretários de Estado e ministros. Em seguida, por iniciativa do Rolf, passei a viajar para outros estados, com o objetivo de fazer coberturas e matérias especiais. Cobri, por exemplo, a primeira greve no nordeste depois da eclosão do golpe de 1964, o lançamento de planos de desenvolvimento pela Sudene [Superintendência para o Desenvolvimento do Nordeste], em Recife, o anúncio do lançamento da Transamazônica, em Manaus, a expansão do parque industrial de Camaçari, em Salvador. Vivia num avião, conhecendo o Brasil para cima e para baixo, me especializando em temas de desenvolvimento. $E$, em seguida, ficou decidido que eu também teria fazer matérias especiais sobre o Congresso, em Brasília, o que me levou a cobrir o lançamento dos autênticos do MDB, convenções desse partido e da Arena, a anti-candidatura de Ulysses Guimarães em 1974 e a posse de Geisel, na presidência.

la a Brasília a cada 40 dias. E, no intervalo, fazia outras viagens, principalmente para o Rio, que ainda sediava ministérios muito importantes. Vai ficando evidente que, por causa dessa movimentação toda, fui aluno relapso nos dois primeiros anos do Largo São Francisco. Mas não perdi nada porque a maioria dos professores - especialmente os de Teoria do Estado, Direito Civil e Ciência das Finanças - eram medíocres. Eu cabulava as aulas mesmo quando estava sem viajar. 
Do outro lado dos fundos da faculdade estava a Fiesp, que tinha um belo corpo técnico e promovia discussões interessantes sobre economia e desenvolvimento. Elas me atraíam mais do que as aulas de Direito Romano, enfadonhas e folclóricas. Naquela época, não havia segurança na porta nem controle de entrada no prédio da Fiesp. Entrava quem quisesse. E aquilo descortinou um mundo novo, em que se discutia as funções do Estado, a noção de estratégia, a formulação de políticas públicas, a profissionalização da burocracia estatal, a diferença entre função e negócio, planejamento - enfim, em que se discutia um projeto de poder para o Brasil. Mesmo sob uma ditadura, lideranças empresariais áulicas não conseguiram impedir debates protagonizados por empresários como José Mindlin, Dilson Funaro e Laerte Setúbal.

Por fim, também descobri que, no prédio do jornal, do lado da redação do Estadão, havia uma sala toda envidraçada, muito bem montada, com sofás ingleses de capitonê e paredes revestidas de imbuia. Ali ficavam os editorialistas e o local era conhecido como "aquário". Com a pretensão e arrogância da juventude, fiquei fascinado e disse a mim mesmo: "um dia eu vou sentar numa cadeira dessas, um dia vou ser alguém como essas pessoas que estão aqui". Quem eram essas pessoas? Faziam parte da equipe chefiada pelo doutor Júlio e escreviam a opinião do jornal, as chamadas "notas e informações", na página 2. Quando ele e o cunhado, Armando Salles de Oliveira, montaram a USP, em 1935, o governo estadual não tinha dinheiro para pagar bem os professores europeus trazidos por eles. Por isso, para complementar os vencimentos, vários se converteram em editorialistas. E outros, sem vinculação com o jornal, passaram a frequentar a redação. Muitos vinham conversar com os editores do Suplemento Cultural, que havia sido lançado por Antonio Cândido e Décio de Almeida Prado. Um dos principais editorialistas era o português Miguel Urbano Rodrigues, irmão do romancista Urbano Tavares Rodrigues. Marxista ortodoxo e exilado do salazarismo, era quem fazia os editoriais mais conservadores. Vencendo minha timidez, procurei conversar com ele e, quando já não havia formalismo em nosso relacionamento, perguntei: "como você pode ser um marxista 
e trabalhar numa empresa conservadora?". "Uma coisa não tem nada a ver com a outra,", ele me disse, "pois sou apenas um empregado e não um intelectual orgânico da burguesia". Tanto a pergunta quanto a resposta me perseguiram ao longo da vida, depois que, metaforicamente falando, passei a integrar um "aquário" no prédio do Estadão, agora já na avenida Marginal.

Na redação, descobri outros engravatados fascinantes, como Frederico Heller, um velho judeu alemão que era editor de economia do Estadão, autor de uma tese defendida na Alemanha e um dos idealizadores da Associação Nacional de Ensino de Economia. Sempre com um charuto na mão, forte sotaque e um tom irônico corrosivo, um dia ele me parou no "túnel do tempo" - o corredor que ligava 0 "aquário" ao restante da redação, ou seja, que ligava os mais velhos aos mais jovens - e disse: "gosto de você, menino. Tenho aqui um seminário realizado aos sábados $e$ quero que você frequente".

\section{Por que o jovem lê} - "ESTADO" todas

as manhãs?

tienuer ratormac a misndo

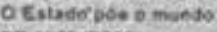
Om vias nact. odos us manast. de ansilues. de forogridios oratede alm

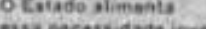
Her mecridado joren Ald o proprio Escads.

ASSIVE OESTAOO OE S PAULO VOCE QUE PTECTSA OE AROUMENTOS:

O ESTADO DE S. PAULO
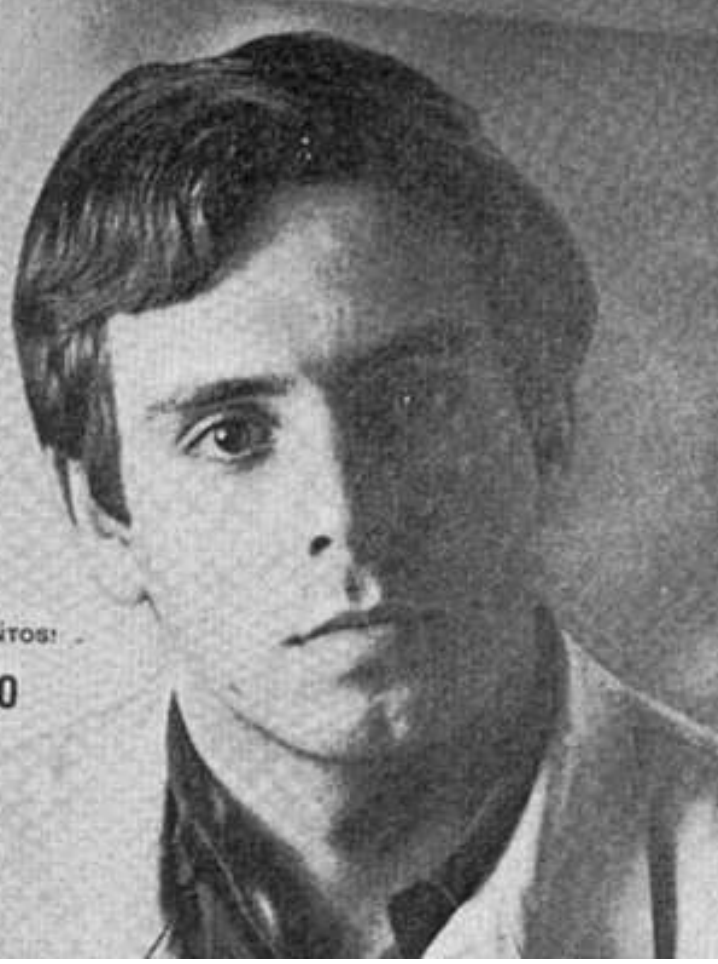

Fonte: O Estado de São Paulo 


\section{O PRIMEIRO SEMINÁRIO}

Eu não sabia que raio era aquele seminário. Jamais soubera de sua existência e pensava que era algo acadêmico. O grupo, bastante restrito, era integrado por Rolf Kunz, por Robert Appy, que tinha feito o doutorado em economia numa universidade francesa, por Arnaldo Alencar Lima, que mais tarde viria a ser executivo de banco, Eduardo Jardim e outros colegas que agora me escapam. Todo os sábados, Heller reunia o grupo para discutir o país e, invariavelmente, convidava um empresário, um banqueiro e um ministro para fazer uma exposição. A regra era o sigilo. Ou seja, as discussões eram abertas e francas, inclusive com informações sobre conflitos dentro da máquina governamental, mas deveriam ficar em absoluto off. Um dos convidados que mais impressionou foi Delfim Netto, um dos mais poderosos ministros da Fazenda que o país já teve. Outro que impressionava era o ministro do Planejamento, Hélio Beltrão, simpático, porém mais opaco do que o Delfim. Este primava pela fluência expositiva, pela inteligência, pela ironia e pela mordacidade. Falando de ministros com quem trombava - e por quem não tinha o menor respeito intelectual -, afirmava que eles eram incapazes sequer de fazer um diagnóstico de suas áreas de atuação. "Quando esse pessoal tenta discutir as reformas estruturais, somos levados a pensar que o inferno é a verdade descoberta tarde demais", dizia. A frase era engraçada da maneira como ele dizia. Mas o autor da metáfora era Thomas Hobbes.

Como o jornal ainda tinha linotipo, e, obviamente, ainda usava chumbo, havia uma limpeza semanal aos sábados de manhã na redação. No meio de pó para tudo quanto era lado, um exército de faxineiras assobiando e esvaziando latas de lixo e a fumaça do charuto do velho Heller, ficávamos num canto discutindo o país. Lembro de um dia em que Delfim, imensamente gordo, sentou numa cadeira bem pequena e começou sua exposição. No meio da bagunça, eu punha a mão na cabeça e dizia para o Rolf: "saindo daqui eu vou para a Maria Antônia assistir a organização de atos de protesto contra a política econômica do governo; e agora, na minha frente, está o responsável pela política 
econômica do governo". No geral, os encontros não tinham nada de acadêmicos. Eram francos, sem linguagem empolada e, por vezes, sem auto-contenção, ou seja, repleto de palavrões. Odiado pelo movimento estudantil e sindical, visto na redação por um jovem repórter ainda sem diploma universitário, o Delfim era inteligente, arguto e, principalmente, divertido. E, claro, também não poupava palavrões e metáforas corrosivas contra seus adversários dentro do governo.

Mais uma vez, a cada seminário, eu lembrava que, três ou quatro anos antes, eu era um adolescente preso a bibliotecas, que desconhecia até mesmo o centro da cidade em que morava. A cada seminário, vendo jornalistas experientes interagirem com formuladores de política pública do país, eu me sentia zonzo com tanta descoberta, como um pinto saindo da casca do ovo. Juntamente com a cobertura que eu fiz na crise estudantil de 1968 e com as matérias no Congresso e em ministérios, em Brasília, esses seminários alargaram minha visão de mundo. Também me levaram à descoberta da frieza que caracteriza certos jornalistas, à descoberta do que, à falta de melhor palavra, pode ser chamado de cinismo. Percebi isso quando, por exemplo, vi um ex-candidato a presidente da República e experiente político entornar xícaras de aguardente no café da Câmara. Os jornalistas passavam por ali e não se espantavam. O cinismo a que me refiro nada mais é do um certo distanciamento, uma espécie de congelamento da emoção. Outro exemplo: naquele período, entrevistei, em várias ocasiões, um importante e conhecido deputado que acabou sendo cassado por ter derrotado fragorosamente o ministro da Justiça, Gama e Silva, em negociações no Congresso. Era um político profissional, o que Weber chamaria de um político que vive da política e não para a política. Cassado no começo da noite, ele desmontou e eu, que o entrevistava, acabei levando ele para casa em meu carro, vendo-o chorar copiosamente. Terceiro exemplo: no dia seguinte à eleição de Geisel, todos os grandes jornalistas políticos do país tentaram entrevistar Ulysses Guimarães para fazer um balanço de sua anti-candidatura. A maior parte não conseguiu. Mas, apesar de estar a 
anos-luz de distância dos experientes colunistas de São Paulo, Rio e Brasília, fui um dos que consegui furar a barreira e passar uma manhã com ele, entrevistando-o. Isso não me subiu à cabeça. No táxi, em retorno ao jornal, percebi que ele tinha me usado. Se desse uma entrevista a todos os colunistas, o impacto na mídia duraria apenas um dia. Se desse uma entrevista a um único repórter, haveria repercussão nos diferentes jornais nos dias seguintes, mas Ulysses correria o risco de se queimar com jornalistas amigos. Ao escolher um jovem e inexperiente, como eu, ele nada mais fez do que implementar uma estratégia: o JT publicou minha entrevista num dia, os jornais a repercutiram nos dias seguintes, Ulysses não se queimou com o "reportariado" político e eu nada mais fui do que um dos cordéis de sua ação política. A consciência disso foi decisiva para minha carreira universitária. O cinismo a que me refiro é a frieza do olhar crítico. Isso não quer dizer nem o desprezo a princípios morais nem desfaçatez, mas, isto sim, capacidade de desnudar falas e desconstruir narrativas - uma imunização que evite tomar os fatos e os discursos pelo seu valor de face e ajude a separar o joio do trigo, em matéria de seriedade e populismo acadêmico. Depois de ter me enredado em textos de Weber sobre metodologia, compreendi que o entendia como cinismo podia ser chamado de ceticismo da razão.

No fundo, venho de uma família tradicional, muito reverencial, capaz de respeitar todas as hierarquias. Meu pai nunca foi chamado de "você" pelos filhos, nunca disse um palavrão, era sempre tratado como senhor aqui, senhor ali; por pouco meus irmãos não o chamavam de "excelência". Aquilo me travou durante a infância e a adolescência. O jornalismo rompeu esse cenário de liturgia, submissão e poder simbólico. Tomei consciência disso quando deixei de me chocar com palavrões ditos nos seminários do velho Heller por alguns empresários e ministros conhecidos e também quando comecei a perceber que os procedimentos solenes no Salão Nobre das Arcadas tinham um ar teatral por vezes over, desconectado da realidade e que as arguições nos concursos de doutorado, livre-docência e titularidade por vezes eram farisaicas e farsescas. 
O jornalismo me emancipou. Quando finalmente compreendi que tinha me libertado do peso da tradição familiar, o que coincidiu com a conclusão de meu curso no Largo São Francisco - eu não fui na sessão de formatura -, ficou claro para mim que minha vocação não se circunscrevia apenas à redação de um jornal. Sem preparo intelectual e sem rigor, meus interesses substantivos seriam demasiadamente ecléticos e jamais teria uma identidade disciplinar. Entre o equilíbrio entre um mínimo de segurança financeira então propiciado pelo JT e os riscos inerentes a uma carreira acadêmica, com todas as contingências dos concursos, percebi que não poderia hesitar. Entre a convicção do que eu queria e o conforto do que já tinha conseguido até então, não tive dúvida e imediatamente me preparei para disputar uma vaga no curso de pós-graduação no próprio Largo São Francisco, na área de Teoria e Filosofia do Direito.

\section{O SEGUNDO SEMINÁRIO}

Foi decorrente desse processo de emancipação e do ingresso na pós-graduação que surgiu um segundo seminário, bem diferente e muito mais rigoroso do que aquele organizados pelo doutor Heller. Ao contrário do primeiro, que era mais jornalístico, o segundo era essencialmente acadêmico. Começou quando o Rolf me chamou de lado e me contou que havia sido contratado como auxiliar de ensino do Departamento de Filosofia, na área de filosofia política, com o endosso de gente como o Bento Prado, [Oswaldo] Porchat e João Paulo Monteiro. A partir daí, nossa relação hierárquica no jornal - editor e repórter - mudou de perfil. Passou a ser de docente e aluno. Acima de tudo, era uma orientação - e uma subsequente avaliação - de leituras. Basicamente, era um trabalho em dupla. De vez em quando, participava das discussões o Reinaldo Lobo, editorialista do JT formado em filosofia pela USP e hoje um respeitado psicanalista.

A primeira carga de leituras foi de autores vinculados à teoria funcionalista. A ideia era estudar modelos funcionalistas do equilíbrio, o que, em princípio, forneceria a base 
conceitual e teórica para a compreensão da instabilidade intrínseca da economia e de uma sociedade como a brasileira, com seu desequilíbrio permanente e sua tendência contínua a crises. Comecei a ler artigos e livros de Sidney Verba, David Easton, Gabriel Almond, Amitai Etzioni, David Apter, Samuel Eisenstadt, Samuel Hungtington e Talcott Parsons. De todos eles, Parsons foi o trampolim para as leituras de Schumpeter e, principalmente, de Weber. Foram dois ou três anos de leitura diária e maciça de Weber. Nas sextas-feiras à noite e nos sábados ou domingos de plantão, gastávamos horas discutindo essas leituras. Além disso, se tivesse algum momento vago, ele era dedicado às questões da construção do Estado e da natureza da sociedade brasileira, a partir de textos de autores europeus, como o francês Jacques Lambert, então em muita evidência, e de clássicos do pensamento social brasileiro, como Oliveira Vianna, Sérgio Buarque e Azevedo Amaral.

Vencida essa etapa, ficou claro que eu também deveria buscar outros ares e interlocutores. Por sugestão do Rolf, do Reinaldo Lobo e de um colega do Largo São Francisco, o Roberto, cujo irmão havia sido assistente do Florestan Fernandes e que, anos depois, chegaria a titular de Sociologia, passei a assistir, como aluno ouvinte, aulas sobre metodologia e teoria social. Um dos professores que escolhi - e que certamente jamais se lembrará de mim, pois não era aluno regular de curso - foi o Jeremias de Oliveira. Fui ouvinte das aulas dele. E, apresentado pelo Rolf em sua casa durante um jantar, conheci outro professor que me marcou, João Paulo Monteiro. Português nascido na cidade do Porto, era filho do Adolfo Casais Monteiro, um poeta e intelectual português exilado aqui no Brasil por causa do salazarismo. Especializado em Hume, João Paulo fez o mestrado em filosofia na USP sob orientação do Bento Prado Jr. e o doutorado sob orientação da Marilena Chauí. Foi professor titular da USP e ensinou em Lisboa, onde faleceu em 2016. As leituras que fiz de vários trabalhos dele foram decisivas para a minha dissertação de mestrado, intitulada Poder e legitimidade, e, mais tarde, para a tese de livre-docência, intitulada Retórica política e ideologia democrática: a legitimação do discurso jurídico. Os trabalhos do João Paulo eram primorosos. Lembro de um jantar com ele, na casa do Rolf, 
em que ele me sugeriu uma leitura rigorosa de Hobbes e ofereceu autores de ponta para balizá-la. Com o que aprendi com o Rolf e como ouvinte das aulas sobre metodologia e teoria social, comecei a me esforçar para ganhar cada vez mais rigor metodológico e domínio conceitual na área que escolhi - a interface do direito com a política e a economia.

\section{A FACULDADE DE DIREITO}

No curso de graduação, passei a relegar para segundo plano as matérias dogmáticas, como Direito Civil e Processual. Ao mesmo tempo, fui seduzido pelas matérias mais teóricas, como Filosofia do Direito. Foi nos dois anos finais do curso em que finalmente conheci alguns professores. Um deles foi José Carlos Magalhães, da disciplina de Direito Internacional Público. Ele me ajudou muito, principalmente no momento em que comecei a me interessar por relações internacionais profundamente, em função de minhas reportagens no JT sobre a questão do desenvolvimento. Como repórter encarregado de cobrir a Sudene e o Banco Nacional do Nordeste, passei a viajar com regularidade a Recife e Fortaleza. Fui conhecendo importantes economistas e sociólogos especializados em desenvolvimento regional. Ainda que fosse muito moço, aos poucos criei uma boa relação com eles, que tinham o dobro da minha idade. Aquelas reportagens foram decisivas para meu crescimento acadêmico e, ao me obrigarem a relacionar desenvolvimento periférico e economias centrais, tive de me enveredar por leituras que me foram sugeridas pelo Magalhães.

Outro professor foi o Tércio, que conheci logo após sua chegada da Alemanha. No início, ele era completamente diferente de tudo aquilo que a Faculdade de Direito tinha em matéria de corpo docente. Estabelecemos um bom diálogo após a primeira aula da disciplina de Filosofia do Direito, no quinto ano. E continuamos a conversar ao final de todas as demais aulas. Com o tempo, eu o levei a escrever artigos para o JT, copidescando 
os textos e botando leads palatáveis. Depois do seminário do velho Heller e do seminário do Rolf, passei a ser orientado pelo Tércio nas leituras jurídicas. Fui convidado para ser seu monitor, inicialmente, e professor instrutor, em seguida. Isso me levou a deixar o Largo São Francisco como aluno, em 1972, e voltar à Faculdade no ano seguinte, como instrutor dos seminários de Filosofia do Direito, iniciando, assim, minha carreira docente. Como o curso era dado no quinto ano, meus primeiros alunos foram meus contemporâneos de faculdade. Tinha apenas 23 anos e, ao entrar na classe pela primeira vez, vindo diretamente do enterro de meu avô, os alunos perguntaram: "mas o que você está fazendo aqui?"

Os seminários do Tércio eram dados aos sábados, de manhã e à tarde e, de repente, no decorrer da década de 1970, eles começaram a crescer, crescer, crescer. Fui ganhando experiência e, um dia, pensamos em criar um centro de estudos e pesquisas na Faculdade de Direito, sediado no Departamento de Filosofia e Teoria Geral do Direito (DFD). 0 projeto foi aprovado formalmente, mas jamais saiu do papel. Para tentar erguê-lo, chegamos a ir com recursos próprios ao Rio e a Brasília, para tentar apoio financeiro da CAPES e vender projetos para a Finep. Anos mais tarde, já na década de 1980, quando Tércio e eu já não trabalhávamos mais juntos, conseguimos criar o Centro de Estudos Direito e Sociedade (CEDISO) com orientandos - como Ana Lúcia Pastore, Maria Cecília MacDowell e Antonio Benedito Margarido - e jovens colegas ingressantes do DFD - como Celso Campilongo e José Reinaldo de Lima Lopes.

\section{7 “ANOS DECISIVOS”}

Voltando um pouco atrás, ainda na década de 1970, vivemos o período mais sombrio da ditadura, marcado por torturas, pelas mortes no Doi-Codi e por censura de imprensa. Naquele momento, já escrevendo a dissertação de mestrado - sob orientação formal do Goffredo [da Silva Telles Jr], que não me deu qualquer sugestão - comecei a me preparar para disputar uma bolsa para fazer o doutorado no exterior. Foi quando surgiram 
dois acontecimentos. Primeiro, fui informado, informalmente, que o jornal não me daria licença, mesmo não remunerada. Os editores do JT me disseram: "se você for agora, nós vamos ter que te substituir". Depois, o Rolf me chama de lado e me diz: "escuta, você está trabalhando cada vez mais com mudança jurídica, mudança social. Você está trabalhando cada vez mais com eficácia e ineficácia do direito numa visão funcionalista, você está cada vez mais preocupado com questões de desenvolvimento econômico e com o papel do direito como instrumento de desenvolvimento. Seu campo de atuação está aqui, não fora. Neste momento, a situação brasileira é absolutamente dramática, com o fracasso do 20 Plano Nacional de Desenvolvimento, que é a espinha dorsal do governo do Geisel. Em vez de ir para fora, onde você vai ser mais um sujeito que vai voltar olhando o Brasil à distância, opte pelo inverso. Fique aqui e faça o pós-doutorado no exterior".

Naquele momento também havia algo importante na minha vida. Deixei de contar que, quando estava no terceiro ano da Faculdade de Direito, um colega me procurou e me disse o seguinte: "vendi um projeto para o Banco Federal de Crédito Itaú Sul-Americano. O projeto foi aceito, mas não consigo desenvolver. Você não quer me ajudar com isso?" $\mathrm{O}$ que aconteceu é que, além de ter iniciado seu processo de informatização, o Itaú - um banco de engenheiros - tinha adquirido o Banco da América - um banco de velhos bancários. Havia uma clara dificuldade de diálogo entre eles e a elaboração de circulares que disciplinassem o cotidiano da matriz e das agências enfrentava dificuldades. Na prática, havia a necessidade de se criar uma extensa e complexa legislação interna na instituição.

Isso foi no final de 1970. Em março de 1971, tornei-me bancário, além de continuar como repórter no JT. E me dei muito bem com a área de tecnologia e processamento de dados do grupo. O diretor dessa área, o Carlos Eduardo Corrêa da Fonseca, foi claro: "Olha, nós temos um problema complicado. O Banco Itaú pertence às famílias Vilela e Setúbal. $O$ doutor Olavo Setúbal tem obsessão pela tecnologia." O Olavo ainda não estava na 
prefeitura. Era o presidente executivo e já havia sido professor de engenharia elétrica da USP, tendo elaborado o projeto elétrico da Cidade Universitária. “Deu um nó aqui, nós não conseguimos fazer com que a área tecnológica se comunique com a área bancária, a área bancária não entende a linguagem técnica dos sistemas que nós estamos trazendo dos Estados Unidos e nós temos que implantar um sistema normativo interno, um sistema de circulares pra padronizar todas as atividades bancárias", disse o Carlos Eduardo, o Karman. Com uma equipe formada no ITA e na Poli, ele me disse que tinham falado para ele de um tal de Kelsen no mundo jurídico. E perguntou se eu não queria me inspirar na concepção de sistema jurídico desse autor para montar um sistema normativo interno no banco, para destravar o nó gerado pelo impasse entre velhos bancários do América e jovens engenheiros eletrônicos do Itaú.

Aí eu falei: "me deem um, dois, três meses, eu tento entender o que está acontecendo". O sistema do Itaú era baseado numa circular AG-2 (Administração Geral n.2), que era uma espécie de norma fundamental do banco. Dali partiam todas as demais normas, agrupadas em circulares por áreas de especialização, como contabilidade, investimento, financiamento, formalização de empréstimos, concessão de crédito etc. Como eu já estudava Kelsen na faculdade desde o primeiro ano, consegui fazer o que foi pedido. Na época, dividia sala com um jovem engenheiro, o Antonio Carlos Barbosa de Oliveira, o Cal, que estava saindo para fazer a pós-graduação no MIT e que, ao voltar, passou a dividir uma área de salas comigo. E me dava muito bem com os responsáveis pelas áreas de sistemas e métodos, Rubens Zaidan e Sérgio Sawaia, também engenheiros. Eu trabalhava no Itaú de manhã, à tarde no jornal e à noite fazia faculdade. Ao entrar para o Itaú, já comecei ganhando mais do que no jornal. Ou seja, minha vida estava se tornando mais complexa.

Eu comecei a atuar como uma espécie de jurista indoor no Itaú e aquilo começou a dar tão certo que passei a integrar o grupo que estava criando a Itautec. Pouco tempo depois, em 1978, o Olavo Setúbal termina o mandato como prefeito, volta para o banco, 
quer continuar na política e passa a precisar de um assessor para assuntos diversos, de caráter não financeiro. O Carlos Eduardo me indicou e fui chamado pelo Olavo para uma entrevista às $8 \mathrm{~h}$ da manhã. Ele tinha uma sala muito ampla, que dividia com o Eudoro Villela, um médico sanitarista, que tinha trabalhado com a cientista Marie Curie em Paris. Era o dono do banco, ainda que não entendesse de gestão bancária. Entrei na sala, inseguro e indeciso. O Olavo olhou bem para mim e disse o seguinte: "soube que você trabalha aqui, quero discutir a possibilidades de você ser meu assessor". E eu, tremendo, respondi: "olha, o senhor tem que me conhecer melhor. Eu escrevo para o Jornal da Tarde, tenho sido muito censurado. Eu fui preso por uma noite em 1968, durante a desocupação da Faculdade de Direito. Não sei se tenho perfil que o senhor deseja". A resposta dele foi desconcertante: "olha, quer saber de uma coisa, gostei do seu currículo. Sou viúvo, não entendo absolutamente nada de mulheres. Mas, como banqueiro, tenho que conceder crédito e aí aprendi a penetrar na alma dos homens. Deles, conheço tudo. Vai dar certo. A partir de agora você vai trabalhar comigo". Em seguida, chamou a secretária e ordenou: "Dona Olden, autorizo a duplicação do salário do doutor Eduardo. Pode dar sala e secretária para ele. A partir de agora ele vai trabalhar meio expediente por dia comigo".

Tomei um susto. Minha vida profissional ganhou mais uma faceta e iniciei uma trajetória de relacionamento profissional e, ao mesmo tempo, fraterno que durou trinta anos, só terminando com a morte dele, em agosto de 2008. Mas, com isso, meu projeto de fazer o doutorado no exterior começou a talhar.

\section{DO CONTEXTO POLÍTICO-INSTITUCIONAL AO CONTEXTO ACADÊMICO}

A dúvida com a opção que tomei começou a esfumaçar com alguns acontecimentos importantes. O primeiro deles são os contatos que vim fazendo com as agências de fomento a pesquisa, principalmente com a CAPES e CNPq. Foi quando conheci o Joaquim Falcão, o Aurélio Wander Bastos, o Mario Brockmann Machado e o Breno da Silveira, entre 
outros. Era um grupo integrado por professores de introdução, filosofia do direito e ciência política com formações distintas, mas que tinha como denominador comum uma postura anti-formalista, uma preocupação com as questões relativas à eficácia do sistema jurídico e a defesa de uma perspectiva sociocultural e sócio-histórica do direito. Era um grupo sensível às dimensões epistemológica, metodológica, histórica e sistemática do direito. Naquele momento, o Centro de Estudos e Pesquisas sobre Ensino do Direito (CEPED), uma experiência bem-sucedida financiada pela Ford Foundation e outras agências americanas, estava entrando em risco porque seus assessores insistiram em incluir as áreas de filosofia e sociologia do direito nos projetos financiados. E isso contou com a oposição do parceiro brasileiro do CEPED, Caio Tácito, um professor de Direito Administrativo dos mais reacionários e raposa felpuda em círculos políticos e empresariais. A experiência não acabou bem. O Caio Tácito não queria qualquer matéria que suscitasse viés crítico no projeto. E, com o tempo, o Joaquim, que dirigia o curso de direito da PUC, teve de se afastar do cargo. Mas foi graças a ele que acabei ingressando nos comitês de área das agências de fomento.

Na CAPES, conheci um pessoal jovem, brilhante e com muitos projetos na cabeça. Eram liderados por um economista mineiro, Cláudio de Moura Castro. À medida que fui me envolvendo com o grupo, via comitê de área, em reuniões em Brasília, fui recebendo conselhos que, de certo modo, repetiam o que o Rolf já me havia dito: "Não vai para o exterior agora, fica aqui. Você está trabalhando com o tema da ineficácia do direito, não vai para o exterior. Queremos conversar com você sobre alguns projetos". Um desses projetos era o Programa de Educação Tutorial (PET). Ele surgiu de uma iniciativa do Cláudio, que se inspirou num programa adotado no curso de economia da UFMG, onde estudou, em Belo Horizonte. A ideia era selecionar, no final do primeiro ano de graduação, os cinco melhores alunos, conceder bolsas de estudo para os próximos quatro anos e leválos a desenvolver leituras, seminários e pesquisas sob orientação de um tutor. Assim, ao se formar, estariam prontos para fazer o doutorado no exterior e retornar, muito jovens, com 
PhD, não só replicando o que aprenderam, mas disputando titularidades em universidades públicas. Uma vez ganhando esses cargos, poderiam modernizar os cursos, já que não teriam os vícios, vieses e preconceitos dos antigos catedráticos. Trocando em miúdos, era um processo de qualificação de elites acadêmicas. Lançados em 1979, os três primeiros PETs foram nas áreas de agricultura e ambiente, economia e direito. Não tenho informação sobre o primeiro dos três. Já o segundo PET foi instalado no curso de economia da PUC do Rio, tendo o Edmar Bacha como tutor. Teve um extraordinário sucesso e, entre outros desdobramentos, formou economistas que optaram pela academia e atuaram nos mais importantes planos de estabilização monetária, como o que levou à substituição do Cruzeiro pelo Real. O terceiro PET foi concedido ao Largo São Francisco, na área de Sociologia Jurídica, com tutoria do Tércio e minha.

Com o rompimento da minha relação com o Tércio, três anos depois de instalado o PET, o grupo ficou sob minha responsabilidade. Todos os anos, selecionávamos cinco bolsistas, que permaneciam trabalhando comigo até a formatura, ou seja, pelo período de quase quatro anos. Os primeiros dois anos eram de formação teórica em sociologia e filosofia, com leituras de Durkheim, Marx e, principalmente, Weber. Nos dois anos restantes, as atividades eram subdivididas. Havia um grupo que se concentrava em teoria social e filosofia, lendo Foucault e Bourdieu, primeiramente, e Luhmann e Habermas, em seguida. E havia um terceiro grupo, o PET-Crime, que se dedicava à criminologia e direito penal. Para cada área, convidava algum orientando de pós-graduação para me ajudar. Dirigi o programa por mais de 30 anos, tendo a tutoria ficado, após minha saída, com o Jean-Paul [Rocha], depois com a Camila [Villard Duran] e, mais tarde, com o Rafael [Maffei]. Não sei de cabeça quantos alunos passaram pelo PET ao longo do tempo. Sei apenas que a maioria esmagadora teve carreira brilhante, tanto nos meios jurídicos quanto nos meios acadêmicos. Dos que me auxiliaram, um chegou a ministro da Justiça no governo do Fernando Henrique. Sete ou oito foram conselheiros do CADE [Conselho 
Administrativo de Defesa Econômica], nos governos do PSDB e do PT. O Celso [Campilongo] é um deles. Alguns chegaram a chefiar a Secretaria de Direito Econômico. Outros ocuparam cargos de ponta no Ministério da Justiça, chegando a dirigir a Secretaria de Assuntos Legislativos. Um fez Instituto Rio Branco e entrou para o Itamaraty. Muitos hoje são promotores, procuradores, juízes e desembargadores na Justiça Estadual e na Justiça Federal. Há quem tenha chegado a ministro do STJ. Há um contingente expressivo de "petianos" que se tornaram pesquisadores do CEBRAP, entre eles a própria Bianca [Tavolari]. E um número significativo de bolsistas permaneceu no mundo acadêmico, tendo ajudado a criar dois cursos de direito, o da São Judas Tadeu e o da Fundação Getúlio Vargas, e até a implantar cursos de pós-graduação em universidades federais. Há ainda quem tenha enveredado pelo jornalismo, chegando a ocupar cargos de direção na Editora Abril e no próprio Estadão. Como o programa era interdisciplinar, temos antigos "petianos" em outras unidades da USP, como o Departamento de Sociologia, de Antropologia e Letras, na Faculdade de Filosofia e no Departamento de Economia da FEA.

O outro acontecimento que me levou a ficar no país, aceitando a ideia de fazer o doutorado na USP e de deixar apenas para fazer o pós-doutorado no exterior, se dá no governo Paulo Egydio, aqui em São Paulo. O Paulo Egydio foi indicado para o Palácio dos Bandeirantes pelo Geisel em 1974, com o objetivo de projetá-lo como um eventual candidato à presidência da República, em 1978, caso houvesse condições para um presidente civil. Obviamente, os porões da ditadura se opunham a isso e tentaram sabotar o governo Geisel de todas as formas. E uma delas foi a violenta repressão do pessoal do antigo II Exército aos meios intelectuais, principalmente jornalísticos. Falo da morte do Vladimir Herzog e das prisões de gente com o Marco Antonio Rocha, meu colega de Estadão, e George Duque Estrada, antigo colega do JT.

A Sandra, com quem casei quando ainda cursava o Largo São Francisco, havia se formado na Fundação Getúlio Vargas e foi uma das melhores alunas de sua geração. Desde o início, decidiu trabalhar com administração pública, jamais quis trabalhar com 
administração privada. E o Paulo Egydio escolhe o Mindlin, da Metal Leve, para ser secretário de Cultura. O Mindlin escolhe o Angarita para ser seu chefe de gabinete. E a Sandra, que havia sido aluna dele, foi chamada para ser oficial de gabinete. O grupo era integrado por gente como Zé Celso de Mello Filho, promotor que mais tarde iria para o Supremo, Flávio Bierrenbach, que seria vereador e deputado, e pela May Rubião, da Metal Leve. A secretaria ficava no Palácio dos Campos Elísios e o Mindlin tinha uma imagem muito boa, como empresário aberto e com posições progressistas no campo político. Na sua queda de braço com Geisel, os porões da ditadura não hesitaram em partir para cima do Paulo Egydio. E o Mindlin, a quem a TV Cultura estava subordinada, foi o alvo do primeiro ataque, que resultou na prisão do Vlado e em seu brutal assassinato.

Aquilo explodiu como uma bomba. Os porões do II Exército não conseguiram justificar o que havia ocorrido, montaram a farsa de que o Vlado teria se suicidado. Uma farsa facilmente desmontada. D. Paulo teve um papel de destaque na mobilização da resistência e alguns personagens surpreenderam. O Ruy Mesquita, diretor do JT, sabendo que a prisão do Marco Antonio era iminente, chamou um médico que atestou as excelentes condições de saúde dele. Com o atestado no bolso, mandou chamar o general Ednardo d'Avila Mello e gente do Estado Maior para diz o seguinte: "O Marco está aqui, eu mesmo o estou trazendo. Sei que vocês estão querendo prendê-lo, só que está aqui o atestado de que ele goza de excelente saúde. Se encostarem a mão no Marco Antônio, vocês vão se ver comigo, com o jornal O Estado de São Paulo, com a Sociedade Interamericana de Imprensa". Mesmo assim, a ofensiva contra o Mindlin continuou, a ponto de algumas pessoas do gabinete terem recebido orientação de não dormir em casa durante alguns dias.

De tanto passar pela secretaria, acabei sendo convidado pelo Mindlin a fazer interpretações sobre o cenário político e sobre a permanência dele no governo Paulo Egydio. Foi um tipo de trabalho iniciado em função das contingências da época, mas pelo 
qual acabei tomando gosto. Tanto que, dali a alguns anos, faria o mesmo para outro empresário do mercado de capitais e, em seguida, para o próprio Olavo Setúbal, no Itaú. O episódio, em suma, fez com que passasse a aceitar que a opção de fazer o doutorado aqui fora acertada.

Há uma segunda ocorrência que reforçou essa convicção. Na época, O Estado tinha um respeitado Suplemento Literário, que havia sido criado nos anos 1950 pelo Décio de Almeida Prado e pelo Antônio Cândido. Mas, diante do clima sombrio dos anos 1970, muitos dos que escreviam ali tinham um viés muito conservador e os mais conservadores eram, de algum modo, vinculados ao Conselho Federal de Cultura, presidido pelo Miguel Reale. No final de dezembro de 1968, o governo havia editado o famigerado Al-5, que serviu de base para que, no início do ano seguinte, vários professores da USP fossem aposentados compulsoriamente, perdendo os direitos políticos. A lista era extensa, tendo incluído o [José Arthur] Giannotti, o Florestan [Fernandes], o Fernando Henrique [Cardoso], o Bento Prado [Jr], a Emília Viotti [da Costa], a Elza Berquó, o Vilanova Artigas e por aí vai. Lembro-me de que, como repórter do JT, fui às pressas para a Reitoria para fazer a cobertura no momento em que os nomes foram divulgados. E aí surgiu uma discussão que, infelizmente, é pouco lembrada hoje em dia. Cassados vários catedráticos e titulares da Faculdade de Filosofia e da Faculdade de Arquitetura, os livre-docentes e adjuntos hipotecaram solidariedade e se recusaram a prestar concurso para preencher as vagas abertas com o tacão do ministro Gama e Silva, um ex-reitor da USP que aproveitou a ocasião para eliminar seus adversários no Conselho Universitário. Com muito bom senso, Florestan chamou esses professores e disse que, independentemente da solidariedade, eles tinham de ser realistas: "Nós fomos cassados, nós não vamos ter condições de voltar. Vocês tem de disputar as cátedras o mais depressa possível, senão o Reale vai fazer o corpo de nível catedrático da Faculdade de Filosofia com esse pessoal do Conselho Federal da Educação". Quem descreve bem o ocorrido é o José de Souza Martins, que foi titular de 
Sociologia na USP, em seu livro autobiográfico ${ }^{5}$. Naquela época, em 1969, os detalhes das conversas com o Florestan me foram passadas por um colega de Largo São Francisco, o Robertinho, irmão do Luís Pereira, livre-docente e assistente do Florestan. Aí ficou claro, para todos, que parte desses candidatos que poderiam vir da direita gravitava em torno de conselhos governamentais. Mas a estratégia dos reacionários acabou não dando certo, já que o Florestan e outros convenceram seus antigos orientandos e assistentes que deveriam disputar os cargos de titular. Alguns dos conservadores eram colaboradores do Suplemento Literário.

Algum tempo depois, o JT havia criado o seu suplemento, um caderno cultural de fim de semana, bem paginado e bem editado. A pedido de Laerte Fernandes, do Fernando Mitre e do Murilo Felisberto, fui, juntamente com o Reinaldo Lobo - tanto o Reinaldo quanto eu éramos editorialistas do Ruy Mesquita -, convidado a dar palpites e sugestões. Naquela hora, era tudo o que eu queria na vida. Primeiro porque aceitaram uma ideia nossa de identificar as lideranças intelectuais das novas gerações, já que o Jornal da Tarde era um jornal leve, transgressor e nós não concorreríamos diretamente com o Estado. De certo modo, foi a forma que encontrada para não por a mão em fio descapado, ou seja, para não trombar com o pessoal do Suplemento Literário. Quem nós trouxemos? Muita gente. O Reinaldinho convidou jovens importantes e brilhantes. De saída, procurei trazer jovens que estavam vindo dos Estados Unidos. Eu tinha uma lista de quem a CAPES e o CNPq haviam financiado no doutorado e fui fazendo convites. Pedi ao Cal, o Antonio Carlos Barbosa de Oliveira, que tinha chegado do MIT e com quem eu trabalhava no banco, que me apresentasse um contemporâneo seu de Cambridge. Eu falei: "chama o Pérsio [Arida] para almoçar". Depois, o convite foi feito para outro egresso daquele grupo, André Lara Resende, então casado com a filha do Hélio Jaguaribe. Em seguida, vieram o Leôncio Martins Rodrigues e a Teca, Maria Tereza Sadek. Do Rio, foram convidados alguns

\footnotetext{
${ }^{5}$ MARTINS, José de Souza. Uma sociologia da vida cotidiana. São Paulo: Contexto, 2014.
} 
membros do luperj, como Marcos Figueiredo e Alexandre de Barros. Wanderley Guilherme dos Santos também escreveu algumas vezes. Era um time de primeira. Um dos mais veteranos, que passou a ser colaborador regular do Caderno de Leituras do JT, sem abrir mão de escrever no Suplemento Literário, foi o Gerard Lebrun. Outro foi Celso Furtado, que morava no Rio, mas uma vez ou outra aparecia para almoçar no prédio do jornal com a equipe do Caderno de Leituras. Tivemos conversas intermitentes, todas muito formais, e, humildemente, pedi sugestões de textos sobre

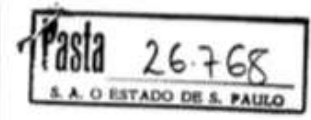
jornalda tarde is DE ABRLL. DE 1999

desenvolvimento a ele. Tinha um fascínio pelo trabalho dele e a cada livro que ele publicava, eu fazia longas resenhas para o JT. Quando ele lançou textos autobiográficos, cheguei a escrever verdadeiras declarações de amor. Eram resenhas longas, pois naquele momento eu tinha a possibilidade de escrever matérias de página inteira ${ }^{6}$.
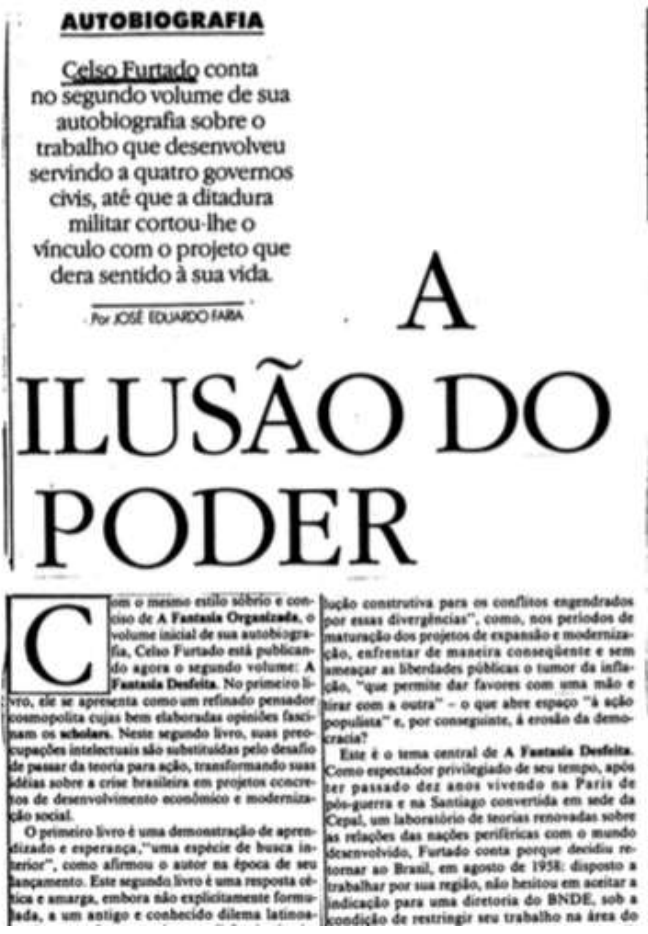

João Paulo Monteiro também escreveu artigos e, graças ao Lebrun, consegui fazer entrevistas extensas com intelectuais franceses como Maurice Duverger e Julien Freund. Cheguei, inclusive, a promover um debate entre o Fpateina Estzdeedbrã Päblbre a metodologia, a sociologia política e a sociologia jurídica de Weber, que foi publicado pelo JT, com uma

\footnotetext{
${ }^{6}$ FARIA, José Eduardo. A ilusão do poder - Celso Furtado conta no segundo volume de sua autobiografia sobre o trabalho que desenvolveu servindo a quatro governos civis, até que a ditadura militar cortou-lhe o vínculo com o projeto que dera sentido à sua vida. Jornal da Tarde, 15 de abril de 1989.
} 
apresentação minha ${ }^{7}$. Essa minha experiência construiu uma sólida ponte entre o jornalismo e a carreira acadêmica.

Essa ponte foi consolidada em 1977, quando propus à direção do JT de fazer uma longa entrevista com o Raymundo Faoro, então presidente da $O A B^{8}$. Ele não era professor e nem tinha doutorado, mas em 1958 havia ganho o mais importante prêmio da Academia Brasileira de Letras com o livro A formação do patronato brasileiro, que mais tarde recebeu o título de Os donos do poder, por sugestão de Érico Veríssimo, que foi seu editor na antiga Livraria e Editora O Globo, de Porto Alegre. Por volta de 1960, Faoro deixou Porto Alegre e mudou-se para o Rio, ganhando o concurso para procurador do Estado da Guanabara. Uma década e meia depois, com apoio da advocacia pública, elegeu-se, por 13 votos contra 11, presidente da $O A B$, derrotando um político e jurista baiano, Josaphat Marinho. Aquele era outro momento bastante sombrio, em que os porões da ditadura continuavam tentando desestabilizar o governo Geisel. E muitos juristas vetustos que apoiaram o golpe militar, em 1964, por frustração e dor de consciência, mudaram de posição e passaram a fazer oposição ferrenha à ditadura. Faoro, que também fazia uma oposição severa, mas tinha jogo de cintura e sabia ler politicamente o cenário, percebeu o risco da postura dos vetustos juristas arrependidos. Quanto mais faziam discursos gongóricos, mais abriam brechas para que os porões da ditadura tentassem derrubar Geisel. Faoro percebeu que o embate entre essas correntes aconteceria no congresso da OAB, a ser realizado em Curitiba, em 1977. Fiz algumas entrevistas com Faoro, todas muito formais, esclarecendo sua posição. Em meio a elas, acabei indo para o Rio antes desse congresso da $\mathrm{OAB}$, para uma nova conversa com Faoro. Nesse encontro, especificamente, que se deu na avenida Marechal Câmara, onde fica a sede do Conselho Federal da OAB, Faoro foi falando sobre o discurso que ia fazer sobre a conjuntura política. Lá pelas tantas,

\footnotetext{
${ }^{7}$ A atualidade de Weber. Jornal da Tarde, Caderno de Programas e Leituras, 1으 de novembro de 1980.

${ }^{8}$ Faoro, em nome da lei. Jornal da Tarde, 6 maio de 1978.
} 
disse que não poderia poupar Geisel, mas também não poderia deixar de aceitar negociar o restabelecimento do habeas corpus como estratégia para evitar que o governo ficasse desestabilizado pela tigrada dos quartéis. Era um raciocínio sofisticado e, vez ou outra, Weber era citado por ele, principalmente a partir da distinção entre legalidade e legitimidade, racionalidade formal e racionalidade material. Enquanto falava, ele punha a mão sobre um livro chamado Poder e legitimidade. Terminada a entrevista, ele pergunta: "você conhece um tal de José Eduardo Faria, seu homônimo lá de São Paulo, que tem uma dissertação de mestrado sobre legitimidade?" Eu respondi: "por acaso conheço. Sou eu mesmo". Ele tomou um susto dos diabos: "Você? Gostei demais da dissertação". Aí mostrou meu livro, por ele inteiramente anotado. E foi aí que me deu, em off, a minuta do discurso que estava preparando para o congresso de Curitiba. Perguntou o que eu achava. Insistiu num ponto: "nunca fui acadêmico". Já eu achei o texto genial, mas com frases extensas. E ele aceitou a sugestão de usar frases mais curtas, que teriam maior efeito ao serem lidas num congresso eminentemente político. A experiência deu certo: ele começou a me mandar cartões, eu passei a enviar artigos, ele me citou em alguns de seus artigos e ensaios. Nunca fomos amigos próximos, mas tivemos uma relação de admiração recíproca.

Certo dia, semanas antes do congresso de Curitiba, Faoro pediu que eu fosse para o Rio. Seria uma entrevista. Na verdade, insistiu para que eu chegasse numa determinada hora, sem atraso. Ao entrar na antessala, vi sentados ali dois ex-ministros da Justiça, o Miguel Seabra Fagundes e o José Eduardo Prado Kelly, e também o Antônio Evaristo de Morais. Faoro introduziu os três em sua sala e pediu que eu assistisse o encontro. Com formação bacharelesca clássica dos juristas, os três foram diretos ao ponto: pediram a Faoro que fizesse, em Curitiba, um discurso radical contra a ditadura e que não perdesse tempo com pequenas negociações. Imaginem só, os três não tinham percebido a importância da estratégia do Faoro. Ele precisava de uma testemunha e eu fui o escolhido. Quando os três foram embora, Faoro explodiu, criticando a alienação e o idealismo - no sentido pejorativo do termo - da fala dos três. Por meio do $J T$, publiquei uma entrevista de 
página inteira com o Faoro às vésperas do congresso. Após a leitura do discurso, escrevi um editorial para o JT, devidamente aprovado pelo Ruy Mesquita, endossando e aplaudindo tudo o que ele afirmara, com rigor, precisão conceitual e inspiração weberiana. $\mathrm{Na}$ entanto, a oposição a ele fez aquele discurso bacharelesco, ecleticamente afrancesado e repleto de jargões típicos de um manual de teoria do Estado. Frustrado, Faoro sequer se candidatou à reeleição. Deu entrevistas ao JT e ao Jornal do Brasil, todas muito amargas. não se candidata a reeleição e vai continuar lendo Weber e escrevendo ensaios, vindo posteriormente para São Paulo, a convite do Instituto de Estudos Avançados da USP, a convite do Carlos Guilherme Motta.

No mesmo mês do congresso da $O A B$, em Curitiba, também escrevi um extenso artigo para o JT, comentando um almoço com importantes liberais da velha guarda e seu papel político naquele momento tenso e sombrio ${ }^{9}$. Tinham sido convidados o Paulo Brossard, então senador; o ex-senador e ex-chanceler Afonso Arinos; e o Goffredo, que havia sido constituinte em 1946. Os três tinham uma retórica empolada e hábitos e costumes conservadores, para não dizer anacrônicos. Mesmo nas conversas informais, comportavam-se como se estivessem numa tribuna. Não falavam, pontificavam. Tudo isso Ihes dava um certo charme. Na última hora, Arinos não pode vir para São Paulo. No artigo, narrei o almoço que, de certo modo, foi uma espécie de egos em revista. Contei que Brossard e Goffredo, juntamente com Arinos, que à época se destacavam como defensores de ideias liberais advindas da Constituição americana de 1787 e do liberalismo inglês do século XIX, vinham canalizando as insatisfações das novas gerações com suas declarações e cartas à Nação. Também ajudavam a dar sentido e coerência às críticas e demandas pela redemocratização. E ainda podiam assegurar uma certa unidade à oposição. Era um artigo altamente elogioso, que comparava os três a uma espécie de São João Batista, aquele que conduziu seu povo mas não exerceu o poder. Brossard ficou encantado com o artigo. Ligou

\footnotetext{
${ }^{9}$ FARIA, José Eduardo. Enquanto o príncipe não vem. Jornal da Tarde, 26 de agosto de 1977.
} 
para mim, leu o texto da tribuna e ainda pediu que entrasse nos anais do Senado. Arinos mandou cartão e convidou-me a passar uma tarde com ele, em sua enorme biblioteca, num casarão da rua Dona Mariana, no Rio. Já o Goffredo e seu entorno não gostaram do texto. Simplesmente, acharam que eu o tratei como ancião, quando, na verdade, minha intenção foi destacar a importância da autoridade moral dos mais antigos, dos mais honrados, dos mais experientes, para lembrar Weber. Foi uma pena.

Naquele momento, tudo o que escrevia no jornal, em matéria de editoriais, reportagens e resenhas, já se convertia em matéria-prima para o meu doutorado.

\section{O CONTEXTO DO DOUTORADO}

Bom, vocês devem estar se perguntando como fica minha carreira acadêmica, onde ficam minhas preocupações docentes. Talvez tenha passado a impressão de que o Largo São Francisco não tinha importância. É justamente o oposto. Os seminários que comecei a dar com o Tércio, entre 1973 e 1975, deram certo. Ele volta para a Alemanha para escrever a livre-docência e, em 1976, o Goffredo me convida para pegar algumas aulas de seminário das turmas dele, no matutino. A experiência também deu certo e ele, que tinha outros auxiliares, acabou me fazendo um pedido: "cuida para mim dos meus seminários, coordena tudo". E me entregou a chefia da equipe dele, tendo eu apenas o mestrado. Entre os demais auxiliares dele, havia doutores. Do dia para a noite, eu fiquei com uma imensa responsabilidade. E tinha uma dissertação de mestrado para apresentar, cujo orientador, do ponto de vista formal, era o próprio Goffredo. O trabalho, intitulado Poder e Legitimidade, parte de três conhecidas perguntas formuladas por Weber, extraídas de $A$ política como vocação. Por que obedecer? Por que e em que condições os homens se submetem? Enfim, em que justificativas internas e em que meios externos se apoia a dominação do homem pelo homem? A ideia foi retomar essas questões à luz da crise de autoridade decorrente dos conflitos estudantis do final da década de 1960, examinar a fusão de legitimidade com legalidade feita pelo positivismo jurídico e discutir o papel 
político exercido pela Constituição, como garantidora das regras do jogo democrático, tratando do problema da legitimidade, mais especificamente da questão dos fundamentos da obediência, a partir da crescente escassez de consenso em sociedades complexas, ou seja, de sociedades marcadas pela multiplicidade, diferenciação e especialização de funções. Publicada pela Editora Perspectiva no mesmo ano em que foi defendia, a dissertação acabou tendo repercussão junto ao alunado, para minha surpresa. Deu respeitabilidade ao professor que tinha uma pesada carga de aulas tanto no matutino quanto no noturno.

Logo após a publicação de Poder e Legitimidade, quem então me chama é o Miguel Reale: "Vou me aposentar em 1979, só quero dar aula de pós-graduação. O Goffredo me falou que você vai bem, fica você com isso". Foi aí, então, que também passei a dar as aulas de Filosofia do Direito nos cursos matutino e noturno, acumulando com os seminários do Goffredo. De um lado, isso me deu prestígio dentro da escola e acelerou a necessidade de fazer meu doutorado. De outro lado, tirou o pouco de tempo de que eu ainda dispunha. Lecionava nas primeiras horas da manhã, trabalhava no banco, trabalhava no jornal, tinha as leituras orientadas pelo Rolf, principalmente sobre Weber, por um lado, e Rousseau e Hobbes, por outro. Foi quando começaram a surgir os primeiros problemas acadêmicos. Como a carga acadêmica ficou pesada, o Reale convidou dois outros professores, um do Departamento de Direito do Trabalho e outro do Departamento de Direito Internacional, para dividir as aulas. Ambos eram livre-docentes, ou seja, tinham dois graus mais do que eu na hierarquia acadêmica. Um deles não criou a menor dificuldade na escolha dos horários. Já o outro invocou a hierarquia e exigiu os melhores horários e as melhores turmas. Me condenou a pegar as turmas noturnas, nos horários finais. Aquilo desmontou meu cronograma de atividades. Fui obrigado a reduzir os seminários do Goffredo. Para minha surpresa, alguns alunos da turma da manhã, entre eles a Mônica MacBritton, hoje professora na Università del Salento, o Otavinho Frias, hoje diretor da Folha, e Taís 
Gasparian, hoje advogada especializada em direito de imprensa, passaram a assistir as aulas de Filosofia do Direito no noturno. Lembro-me de que, num certo dia, Otavinho me procura em casa e pede para que eu tentasse promover uma aproximação entre a família Frias e a família Mesquita, proprietária dos dois jornais mais importantes de São Paulo. Além da competição comercial, elas não se falavam, o que não fazia o menor sentido naquele momento autoritário em que o país se encontrava. Não fazia o menor sentido que, num contexto de censura, os responsáveis pelos dois jornais não dialogassem, tendo em vista os interesses maiores das liberdades públicas. Fiz a proposta ao Ruy Mesquita e invoquei esse argumento, que foi por ele aceito de imediato. Depois de um jantar com o Otavinho e a quarta geração da família Mesquita, levei-o a conhecer o Ruy e o prédio do Estadão. Isso aconteceu de maneira mais do que educada: foi uma relação inicial generosa. E falar que isso surgiu de uma relação de aluno com professor em sala de aula.

Desprezando as inevitáveis picuinhas daí advindas, além das aulas, passei a me concentrar no doutorado, já que estava concluindo os créditos. Havia decidido discutir a transição do autoritarismo para a democracia, a questão do desenvolvimento econômico e a utilização do direito como instrumento de planejamento e crescimento. Se normas, instituições sociais, capitais e confiança desempenham papéis críticos no funcionamento da economia, como lidar com elas a partir de um processo de planejamento que se propõe a organizar racionalmente o sistema econômico a partir de determinadas hipóteses sobre a realidade? Hipóteses essas que, naquele momento, no país, não vinham sendo discutidas democraticamente, mas impostas de cima para baixo por um governo presidido por um militar avesso ao diálogo? Um general que presidira a Petrobrás e não percebera o impacto da crise do petróleo na economia mundial? O pano de fundo do meu projeto envolvia o $2^{\circ}$ Plano Nacional de Desenvolvimento, que propunha o deslocamento do setor automotriz para o setor petroquímico, como eixo do desenvolvimento brasileiro, mantendo uma matriz energética baseado no petróleo, cujos preços haviam explodido com a criação da Opep e com a subsequente redução na oferta de óleo e, assim, com o 
aumento do preço do barril. Além disso, o $2^{\circ}$ PND inverteu os critérios de distribuição de incentivos para regiões menos favorecidas, levando o governo a perder apoio político do empresariado. Também privilegiou grupos nacionais em áreas estratégicas, como Villares, Bardella e Cobrasma, e investiu em infraestrutura com o objetivo de atender à demanda prevista para o ano 2000. Em suma, se era evidente que o simples jogo das forças de mercado, com pouca intervenção do poder público, não levaria ao crescimento, também era evidente que um processo autoritário de planejamento, definido a partir de visões equivocadas da ordem econômica mundial e da própria realidade do país, estava fadado ao fracasso. Estávamos em 1974 e 1975 e o plano, elaborado pelo Ministro do Planejamento, Reis Veloso, sob rígida orientação de Geisel, era duramente criticado pelo ministro da Fazenda, Mário Henrique Simonsen. "Não leio obras de ficção", dizia ele, quando perguntado sobre o $2^{\circ}$ PND.

Minha sensibilidade para essa discussão foi então se aprofundando, me levando a privilegiar reportagens nessa área no JT. Já falei das matérias sobre o Celso Furtado, da interlocução com o Raymundo Faoro e das aulas que havia assistido, como ouvinte, em outras unidades da USP. Graças ao jornal, mantinha contatos com o pessoal da Sudene e do BNB, o que sempre me auxiliou. Além de me mandar cobrir os dois órgãos, entre Fortaleza e Recife, o jornal estimulou que eu me aproximasse da Fundação Getúlio Vargas, ampliando com isso meu interesse sobre matérias relacionadas ao desenvolvimento, planejamento, interação entre direito e economia e eficácia jurídica. Nessa época, Karl Mannheim era o autor referencial numa discussão que, partindo da distinção entre planejamento compulsório para o poder público e planejamento indicativo para a iniciativa privada, discutia o quão antinômicos eram os conceitos de política e planejamento. A ideia era que o planejamento, visto como instrumento de política econômica, era um processo de distribuição racional e ótima de recursos escassos e dos meios, com base em objetivos sociais e econômicos previamente definidos. Esses objetivos, contudo, seriam resultantes 
de decisões políticas, decisões essas que, por advirem da vontade de determinados grupos e classes, estariam vinculadas a uma esfera não racionalizada da vida social. Tentando conjugar liberdade individual, representatividade de grupos de interesse, multiplicidade de objetivos e organização racional do sistema econômico, Mannheim falava em planejamento democrático. Lembro-me de ter ouvido o então professor Fernando Henrique ter falado de Mannheim, numa palestra que cobri.

A discussão se tornou tão acirrada no início dos anos 1970, que o Prêmio Nobel de Economia de 1974 acabou sendo concedido a dois economistas com visões diametralmente opostas: ao sueco Gunnar Myrdal, defensor do planejamento democrático, e ao conservador filósofo e economista austríaco Friedrich Hayek, crítico feroz da presença do Estado na vida econômica e social. Pelas contingências da vida, estava no Rio a trabalho quando Myrdal esteve na FGV para uma palestra, tendo aproveitado a ocasião não apenas para cobrir o evento, mas também para entrevistá-lo. $\mathrm{Na}$ conversa, expliquei a ele meu projeto de pesquisa e acabei recebendo uma surpreendente lista de leituras de textos a que eu jamais teria acesso, se não tivesse contato com ele. Com Hayek, deu-se o contrário. Eu o conheci quando ele foi convidado, pela família Mesquita, para uma palestra no auditório do jornal. Depois, eu o revi quando se tornou uma espécie de orientador intelectual de um empresário polêmico, Henry Maksoud, que havia comprado a revista Visão, tornando-a uma espécie de divulgadora das ideias de Hayek. Mas, apesar de educado, era um sujeito frio e pedante. Não deu diálogo "no start", como se dizia no banco.

Enquanto concluía os créditos e começava a escrever os primeiros capítulos do doutorado, o Departamento de Filosofia e Teoria Geral do Direito se transformava. Goffredo se aposentou por volta de 1978 e Reale teria de sair em 1979. O candidato natural à vaga do Goffredo era Teófilo Cavalcanti Filho, muito próximo da dupla. E, para a vaga do Reale, o candidato natural seria o Tércio, recém chegado de mais um estágio na Alemanha, já que os outros livre-docentes tinham pouca produção acadêmica. Seria uma 
transição tranquila. Mas, como vocês sabem, acabou sendo tumultuada. Primeiro, porque o Teófilo teve um infarto fulminante. Ele morreu quatro meses antes do prazo para depósito da tese. Reale logo percebeu que alguns professores de filosofia do direito de universidades federais de outras regiões ficaram assanhados para disputar a vaga do Goffredo. O Reale dizia, com aquele autoritarismo típico dele: "Do norte, do nordeste ou do sul não vem ninguém, nós temos que produzir um professor titular aqui, nós somos endogâmicos, somos a USP". E aí olha para o Tércio e fala: "tem de ser você". Surpreendido, o Tércio achava que não tinha condição de escrever uma tese em quatro meses. E como estávamos então muito ligados, digo o seguinte: "dá, sim. Você escreveu um livro chamado 'A Ciência do Direito', que eu reputo como sendo seu melhor livro, melhor do que a tese de livre-docência". Eu não contei aqui para vocês, mas o Tércio foi uma das pessoas que eu levei para o Caderno Cultural do JT. Durante dez anos, quem o pautou, quem reescreveu os artigos dele fui eu. Ele ganhava bem pelos artigos, o que ajudava nas despesas de casa, já que, na época, só vivia da USP. Por isso eu falei, “a gente pega todos esses trabalhos que você publicou no JT e no Estado. Você transforma isso em aula, com um gravador na frente. Você vai muito bem em aula, mas ainda escreve textos meio pesadões. A gente arruma alguém que degrave e eu edito isso para você". Então se você olhar a tese de titularidade dele e comparar com as demais teses e livros, verá que ela tem um texto jornalístico.

Disputando só, e com apoio do Reale, o Tércio ganha o concurso. Aí então foi o momento que achei que ele conseguiria liderar um grupo que oxigenasse o Largo São Francisco. Naquele momento, os comitês de área da Capes e do CNPq, dos quais cheguei a fazer parte durante algum tempo, defendiam uma reforma estrutural nos cursos jurídicos. Os relatórios das duas agências eram claros: "a teoria jurídica precisa acompanhar o desenvolvimento socioeconômico, mas o que tem feito é trabalhar com categorias tradicionais, modelos fechados, visões formalistas e soluções abstratas. $O$ direito 
transformou-se num mero instrumento casuístico do poder autoritário e pragmaticamente dirigido para remover obstáculos e interceptar o processo de consolidação democrática", dizia um relatório do CNPq de 1978. Vejam vocês, estávamos em plena ditadura militar e isso era dito por um grupo de jovens professores de teoria e filosofia do direito num texto oficial. "Na medida em que as faculdades de direito encontram-se fechadas à pesquisa jurídica, seja ela científica ou não, o país começa a criar outros órgãos geradores do conhecimento jurídico. Os projetos apresentados ao CNPq não são elaborados com nítidos suportes metodológicos, nem muito menos demonstram que os bolsistas têm exata informação sobre o universo, o objetivo e as fontes de pesquisa jurídica em que deveriam apoiar suas investigações", diz o relatório do ano seguinte. Participei da redação de alguns e devo ter cópia de todos eles aqui na biblioteca. Todos os membros desses comitês eram muito jovens. As reuniões ocorriam em hotéis de Teresópolis ou Petrópolis. Eu as achava fascinantes. O que aprendi com o Joaquim, o Mário Machado, o Breno e o Aurélio, naquelas reuniões entre 1978 e 1984, quando os relatórios eram preparados e os planos quinquenais de área eram discutidos, foi decisivo para eu acabasse integrando a Comissão de Reforma do Ensino Superior, em 1985, e sendo convidado no ano seguinte pelo Flávio Fava de Morais para integrar a coordenadoria de ciências humanas da Fapesp.

Concluí o doutorado em 1981, sem jamais ter deixado de lecionar durante esse período. Com o título, subi um degrau na hierarquia da USP e descubro, então, que aquela oxigenação do Largo São Francisco que eu imaginava ser possível com a ascensão do Tércio a titular, patinava. Entre outros motivos, porque a sucessão do Reale tinha se convertido num conflito tão acirrado, a ponto de ser necessário trazer da Itália um professor licenciado da escola, Renato Cirell Czerna, que já estava próximo dos 70 anos. A ideia era que ocupasse a titularidade por uns dois anos, para que se pudesse retomar a sensatez durante esse período. Para se ter ideia da confusão então reinante, o Tércio acabou sendo incluído na lista tríplice para diretoria da Escola de Comunicações e Artes (ECA). O reitor da USP o escolheu e ele só não assumiu o cargo porque o Reale interferiu, alegando que ele 
estaria liquidando a carreira como filósofo do direito. Assisti a pelo menos uma reunião dessas, em que o Reale exigiu ao Tércio que ficasse no Largo São Francisco, depois de tanto esforço para evitar que a vaga aberta pelo Goffredo fosse ocupada por docentes vindos de fora.

Nesse contexto, surgem mais dois problemas, ambos complicados. Meu pai, que era titular da FEA e do Largo e estava na chefia do departamento, morre em 1981 de infarto fulminante, o que leva o Tércio a sucedê-lo. Como filho mais velho, tive de liderar uma família de cinco irmãos, um dos quais estava saindo da adolescência. Fechei o escritório de advocacia dele, tive de reordenar o dinheiro dele, que estava pessimamente investido, providenciar inventário etc. O segundo problema foi a abertura da vaga de titular decorrente da morte do meu pai. A vaga do Reale, aposentado pela compulsória, tinha sido aberta meses antes.

\section{ESTADOS UNIDOS, ESPANHA E FRANÇA}

Nesse período, ganho uma bolsa de estudos nos Estados Unidos, que, finalmente, pude gozar. Era uma bolsa absolutamente invejável, com excelente grant e uma série de outros benefícios, dos quais os mais importantes eram um passe aéreo para qualquer lugar do país e verbas para hotel, alimentação e transporte. Meu primeiro estágio foi na Georgetown University. Em seguida, fiz uma proposta de conhecer Harvard, o MIT, Columbia, a New School for Social Research, Chicago University, Berkeley, Stanford e Wisconsin. A proposta foi aceita. E, por causa de minhas preocupações com desenvolvimento regional, tema que me levou a escrever muitas matérias sobre a Sudene, conheci também a Tennesse Valley Authority. Também aproveitei a oportunidade para conhecer possíveis orientadores no pós-doutorado e providenciar as applications. Em Chicago, por exemplo, conheci o Philippe Schmitter. Em Stanford, almocei e jantei com professores cujos livros lera sob orientação do Rolf, como Gabriel Almond e Sidney Verba. 
Conheci, igualmente, o sucessor de David Easton, Robert Packenham, um dos críticos mais severos dos trabalhos de Fernando Henrique sobre teoria da dependência. Em Harvard, conheci Henry Steiner, com quem estaria dois anos depois acompanhando uma pesquisa do Joaquim sobre ocupação de terras em Recife e Olinda. Ao final da bolsa, dei-me uns dez dias de férias na cidade do México, onde tinha uma amiga, Valquíria Wey, que trabalhava na área cultural da embaixada brasileira e assessorava o filósofo Leopoldo Zea, no Instituto de Estudos Latino-Americanos. Meu objetivo era conhecer a Universidad Autónoma de México e flanar por museus, especialmente o Antropológico e o de Belas Artes. Mas acabei acertando com a Valquíria a preparação de um extenso artigo sobre a crise política brasileira, que foi publicado um ano depois. Também acabei conhecendo um grupo de exilados brasileiros, com quem me enturmei, e dos quais se destacavam o ex-deputado maranhense Neiva Moreira e o sociólogo Herbert de Souza Filho. Um dia antes de voltar para o Brasil, o Betinho pergunta se eu poderia levar para o irmão, o cartunista, Henfil, alguns livros e um envelope muitíssimo bem fechado entre eles. Como tinha franquia de peso, por causa da bolsa, aceitei na hora o que me foi pedido. Na verdade, já vinha trazendo de São Francisco, de onde tinha embarcado para o México, vários livros pedidos por uma amiga historiadora, de formação marxista, que trabalhava comigo no banco e estava terminando o doutorado. O Betinho estava preocupado com o risco de eu ser revistado no desembarque, mas eu o tranquilizei, dizendo que chegaria a São Paulo num voo da Braniff que pousaria num aeroporto pouco movimentado, Viracopos, e num sábado à noite, quando não deveria haver movimento e a fiscalização seria burocrática. No despacho da bagagem, achei melhor tirar o envelope lacrado do meio dos livros e deixá-lo junto aos meus documentos relativos à bolsa, onde estavam as notas fiscais que teria de apresentar. Ao pegar as malas em Viracopos, fui o único passageiro revistado. Já esperavam por mim. Abriram todas as malas, folhearam todos os livros para ver o que tinha dentro e fizeram perguntas óbvias, inclusive sobre o conteúdo dos livros, mas não se interessaram pela pasta plástica onde trazia os documentos e o envelope. No final, 
apreenderam dois livros, um deles sobre Weber, vejam só. Nada aconteceu com os livros do Betinho e os da minha amiga historiadora. Fiquei com a sensação de que tinha sido observado no check-in da Braniff. Meses depois, numa aula na UnB, em Brasília, uma aluna de pós me contou que tinha ficado sabendo do que aconteceu naquela ocasião. O pai era um político influente, à época.

O fato é que essa bolsa não apenas reafirmou a vontade de fazer um pós-doutorado nos Estados Unidos, como também me estimulou a fazer a livre-docência. Pedi licença no banco, que me foi dada pelo Olavo Setúbal, e no JT, que me foi dada pelo Ruy Mesquita. Mas, em vez de retornar aos Estados Unidos, fui para a Espanha e a França. O título da tese é Retórica Política e Ideologia Democrática. É um trabalho eminente teórico, ao contrário do doutorado. É uma sequência natural das pesquisas que tinha feito para o mestrado, Basicamente, consiste numa tentativa de discutir como os modelos liberais de organização política e jurídica lidam com a crescente complexidade socioeconômica de sociedades em desenvolvimento. A ideia foi examinar o papel de ficções, como os princípios da neutralidade do legislador, da imparcialidade da lei, da unidade sistêmica dos códigos e da igualdade formal no processo de produção do convencimento jurídico. Foi analisar algumas concepções legadas pelo contratualismo clássico e retomar criticamente, sob a ótica do pensamento jurídico, questões como acesso ao poder, equilíbrio entre a segurança do Estado e a liberdade dos cidadãos, a articulação entre movimentos sociais e organismos institucionais e a emergência de processos de transformação social, por meio dos quais as reivindicações de justiça transcendem o plano da igualdade perante a lei, exigindo direitos sociais cuja efetividade dependeria da formulação e implementação de políticas públicas. Foram vitais o diálogo com o Rolf, conversas intermitentes com Lebrun, que por vezes almoçava no jornal, e os textos sugeridos por outros professores, como o argentino Luis Alberto Warat e o português Boaventura de Sousa Santos, de quem me tornei amigo fraternal, a ponto de tê-lo trazido para trabalhar no Instituto de Estudos 
Avançados, em 1988. Os textos de João Paulo Monteiro também me abriram os olhos para a necessidade de rigor na leitura de alguns autores, como Hobbes. Estava inseguro, porque sempre havia visto a livre-docência como um dos títulos mais importantes das USP. Mas, naquele momento, era estimulado a fazê-la como um rito de passagem, para me habilitar à disputa de uma das duas vagas de titularidade abertas no departamento. Tive a prudência de me concentrar na livre-docência. E, para minha surpresa, fui aprovado com notas excelentes por uma banca integrada Nelson de Souza Sampaio, que foi professor de Ciência Política da Bahia, formado nos Estados Unidos, e que tinha sido deputado pela UDN; pelo pernambucano Lourival Vilanova, da área de Filosofia do Direito; pelo Warat, professor de Teoria do Direito, e pelo Dalmo Dallari, professor de Teoria do Estado.

Terminada essa etapa, minha disposição era passar um período fora. Só que, em seguida, retornam as pressões para que me candidatasse a uma das vagas de titular. No primeiro momento, rejeitei a ideia. Mas logo em seguida me candidatei a uma nova bolsa, financiada pela Fulbright Commission, e fui agraciado. O que eu não contei a vocês é que, naquela bolsa anterior, por sugestão de alguns amigos, visitei a Wisconsin University, no campus de Madison. Naquela época, meu irmão fazia o doutorado dele em medicina em Stanford e havia ficado encantado com Palo Alto e São Francisco, com a maneira como ele foi tratado. Eu também tinha sido tratado muito bem por lá, quando fui visitar. Henry Steiner também se propôs a me ajudar para que fosse aceito em Harvard. Stanford e Harvard eram minhas preferências. Mas, aproveitando a bolsa anterior, eu conheci David Trubek, cuja orientação mudaria os rumos das minhas pesquisas, e a cidade de Madison foi amor à primeira vista. Dave tinha uma capacidade de diálogo e um acolhimento que eu não teria em outro lugar, por maior que tivesse sido o refinamento com que fui tratado em Stanford e Harvard. E, um dia conversando com o Joaquim, numa dessas reuniões do CNPq, ele me disse: "você é um maluco, se ficar em Harvard. O Steiner viaja muito, o Mangabeira viaja muito. Vão oferecer um jantar a você quando você chegar e outro de 
despedida, quando tiver retornando. Você não vai conversar muito com eles, vão te dar uma jaulinha na biblioteca, só. O Trubek vai te adotar, você vai ficar amigo do Trubek".

Optei por Madison e ocorreu tudo o que o Joaquim havia dito. De saída, Dave me deu uma sala de um professor que estava licenciado. Deu-me a prerrogativa de frequentar a Faculty Club. Apresentou-me para todo mundo e conseguiu que eu tivesse um passe aéreo para viajar com o objetivo de entrevistar quem eu quisesse. Apresentou-me para todo o pessoal da sociologia do direito, o pessoal mais inclinado às discussões teóricas e o pessoal voltado a pesquisas empíricas. Do dia para noite, passei a tomar café e a almoçar com o Marc Galanter, que tinha sala exatamente debaixo da minha, com o Joe Thome e com o Stewart Macaulay. E ainda mandou buscar todos os livros que poderiam ser úteis para minha pesquisa. Um dos textos que me passou foi um depoimento meio ensaístico de um subministro da Justiça do então presidente chileno Salvador Allende, chamado José Antonio Vieira Gallo. Era um texto sobre os problemas enfrentados por socialistas eleitos democraticamente - como Allende - para postos-chave do Executivo. Era sobre problemas ao terem de administrar, sem maioria absoluta no Congresso, por um lado, e a terem de se submeter a um sistema jurídico burguês, por outro lado. Era um texto extenso e instigante, sobre o significado da vitória do chamado "governo popular" e o papel do direito na construção do socialismo no Chile. Era um trabalho que contrapunha efervescência revolucionária e Estado de Direito; que contrapunha discussões relativas à legalidade de certos atos do governo socialista e o respeito à concepção jurídica de propriedade privada; que indagava sobre os limites do redirecionamento de uma ordem jurídica escrita por conservadores e liberais rumo a princípios socialistas e a uma governabilidade socialista. Em suma, era um texto polêmico. Gostei tanto, que o acabei trazendo para o Brasil, traduzindo-o e conseguindo que o Miguel Pressburger o publicasse num dos Cadernos Insurgentes do Ajup (Instituto Apoio Jurídico Popular), ali por volta de 1988 ou 1989, não 
me lembro ao certo ${ }^{10}$. O que sei é que começava a primeira campanha presidencial pelo voto direto em 30 anos. A energia e a competência do Miguel eram impressionantes e a iniciativa dele teve grande êxito. Tanto que, com a surpreendente chegada de Lula no segundo turno, juntamente com outro azarão, Fernando, o texto do Vieira Gallo acabou sendo utilizado por políticos do PT e pelo pessoal vinculado ao Lula. A procura pelo texto foi tão grande que pedi aos editores do JT que o republicassem, o que ocorreu dias após a eleição.

A verdade é que a experiência que tive em Madison foi como entrar no paraíso. Durante minha estadia por lá, fiquei uns seis meses só. Depois Sandra chegou com o André, que era pequeno. Passei todo o período lendo, escrevendo, lendo, reescrevendo. E disso resultou um trabalho que acabei apresentando no Largo São Francisco como tese para professor titular, intitulado Eficácia jurídica e violência simbólica. Basicamente, é um trabalho sobre a eficácia do direito numa sociedade periférica, como o Brasil. É um trabalho sobre os graus de penetrabilidade do direito em contextos sociais heterogêneos e divididos, como o brasileiro. É um trabalho em que me valho muito da ideia de violência simbólica desenvolvida pelo Bourdieu, ou seja, uma forma de violência exercida sem coação física e que se apoia no reconhecimento de uma determinada imposição econômica, social ou cultural. A violência simbólica se dá pela produção contínua de crenças no processo de socialização, crenças essas que levam os indivíduos a se posicionar nos espaços sociais segundo do critérios e padrões do discurso dominante. Nessa linha de raciocínio, o direito resulta de relações de força entre os teóricos e os profissionais da prática jurídica. Os juristas são responsáveis pela codificação, que gera efeitos de racionalização, universalização e normalização. Isso faz com que o direito ganhe sua força específica. A partir daí, várias perguntas são possíveis. De que modo o direito se relaciona com o poder social, econômico político e cultural? Em que medida o jurista pode se tornar

\footnotetext{
${ }^{10}$ GALLO, José Antônio Vieira. O sistema jurídico e o socialismo. Instituto Apoio Jurídico Popular - FASE, dezembro de 1989.
} 
um agente de transformação social e o direito pode se converter em instrumento dessa transformação? Comecei a ler Bourdieu, que chamava os juristas de "guardiões da hipocrisia coletiva", na época em que fazia parte dos comitês do CNPq, por sugestão de colegas que o integravam.

Quando deixei Madison, com o trabalho pronto e endossado por Dave e seu pessoal, sabia que estava em condições de disputar uma das vagas de titular - e tinha memorial para isso. Mas, ao chegar, fui informado de que um professor de Direito Civil e um professor de Direito Tributário haviam se inscrito no concurso, que não tinham qualquer formação nos campos da Teoria, da Sociologia e da Filosofia do Direito. Eu era muito jovem e eles bem mais velhos e imaginaram que, com a idade, além de pressões políticas, teriam a senioridade para compensar o que desconheciam do campo coberto pelo departamento. Além disso, havia injunções políticas, em função de rivalidades acadêmicas na escola. Daqui e dali começaram a chegar recados de que eu estava fritado, inclusive pelo Tércio. Não acreditei que ele fosse capaz de fazer isso. Infelizmente errei em minha análise. Quando a banca examinadora foi nomeada, as coisas ficaram claras. Um dos membros era o Caio Tácito, aquele professor de direito administrativo da UERJ, de que já falei antes. Presidente do Conselho Federal da Educação, ele ajudou a sepultar a experiência do CEPED, era avesso à Teoria do Direito e via em cada sociólogo do direito um perigoso comunista. Outro era um professor de Direito Comercial do próprio Largo São Francisco. Um terceiro era o Vilanova, cuja conduta prefiro não comentar. O quarto era, supreendentemente, o Tércio. O último, e que agiu com decência durante todo o concurso, era o Edgar Godoy da Mata Machado, professor de Introdução ao Direito na Federal de Minas Gerais, deputado federal cassado em 1968, um homem da Democracia Cristã, leitor de Jacques Maritain, vinculado a Alceu Amoroso Lima e ao Montoro e com um filho morto pela ditadura. 
Entrei no concurso rifado. Eu tinha o dilema de saber o que fazer, se participava do concurso ou se o denunciava. Tinha de fazer uma escolha e decidi concorrer e seja o que Deus quiser. Foi uma experiência abjeta. Logo no primeiro dia, fui chamado pela banca e comunicado de que o Caio Tácito, com beneplácito do Tércio, do Mauro e do Vilanova tinha feito a seguinte proposta: "Embora seja um concurso para a área de Filosofia $e$ Sociologia do Direito, um candidato vem da área de Civil, outro candidato vem da área de Direito Tributário e um terceiro vem da área de Filosofia do Direito Tributário. As condições não são justas. Não há isonomia. É preciso, portanto, que exista uma redivisão dos pontos para que se possa mostrar os brilhos que todos têm nas suas áreas". Bom, eu tomei um susto. A banca tomou essa decisão e eu não pude fazer nada. Pegaram o programa de dez pontos, que havia sido divulgado, e o retalharam. Tinha ponto de Tributário, Civil, Comercial, Processo. O ponto sorteado para a aula, num concurso de Filosofia e Teoria do Direito, teve como tema "o conceito jurídico de empresa". Na arguição, Caio Tácito disse que sociologia do direito não era ciência e me tratou como se eu fosse subversivo. 0 Villanova, de formação analítica, não escondeu o desprezo pela sociologia do direito. A arguição do Mauro Brandão Lopes foi educada, mas sem nenhuma aderência com a temática da tese e da própria área do concurso. Na prova didática, nunca havia lido nada sobre o tema, conceito jurídico de empresa. Por sorte, havia material importante na biblioteca de meu pai, inclusive correspondência sobre isso, travada por ele com o Oscar Barreto Filho, comercialista de sua geração e amigo fraternal. O civilista e o tributarista também não entendiam do tema. O primeiro naufragou. $E$ o segundo, contrariando o regimento, leu um texto que dava a impressão de ter sido escrito a dez mãos. Acabei me saindo melhor do que esperava, tendo recebido o único dez, dado pelo Mata Machado. No memorial, membros da banca chegaram a alegar que pareceres jurídicos de Direito Administrativo e Tributário podiam ser classificados como trabalhos acadêmicos, o que acabou diluindo quantitativamente minha vantagem relativa do ponto de vista qualitativo, 
pois era o único com trabalhos de Teoria, Sociologia e Filosofia do Direito publicados no país e no exterior.

No cômputo final, ganhou o tributarista por uma diferença pequena. Saí diretamente da escola para a maternidade, já que a Sandra tinha entrado em trabalho de parto. Meu filho menor, Murilo, nasceu umas dez horas depois daquela confusão abjeta. Dias após o concurso, recebi um pequeno texto do Mata Machado, me elogiando e contando um pouco dos bastidores. Guardei o papel numa caixa de banco, onde se encontra até hoje. Três ou quatro meses depois, eu morava num apartamento aqui em frente a este, num sábado por volta das quatro horas da tarde, toca o interfone e o porteiro me diz: "tem um tal de Caio Tácito que quer subir pra conversar com o senhor". Mandei subir. Eu estava dando mamadeira para o Murilo, Sandra estava fora, o Caio entra e diz com hipócrita solenidade: "eu quero pedir desculpas. Aconteceu isso e isso, quem manipulou o concurso foi um amigo e sócio do tributarista, Michel Temer. O senhor sabe que eu não gosto de sua ideologia e de suas posições acadêmicas, mas o senhor não pode deixar de continuar seguindo a careira acadêmica. De tudo o que eu falei na arguição, eu retiro isso, isso e isso". A única testemunha presente era um bebê. O examinador que ensinava Comercial também pediu a um sócio de escritório, antigo aluno meu, que me procurasse para saber se eu o receberia para que pedisse desculpas. Mandei o emissário e o interessado a lugar obsceno. E o Villanova, ao me ver um dia no aeroporto de Recife, onde cada um de nós embarcaria para outra cidade, abaixou a cabeça, fez menção de vir ao meu encontro, mas eu simplesmente ignorei.

Meses após o concurso, que se realizou em 1984, sofri um desagravo que surpreendeu não só a mim, mas a todo o departamento e à própria escola. Na comemoração de seus 50 anos, em 1985, a USP, entre outras iniciativas da Reitoria para marcar a data, decidiu publicar pela editora da Universidade algumas teses de titularidade que seriam a marca de qualidade das pesquisas acadêmicas e do pensamento de ponta 
instituição. A ideia era publicar, pela Edusp, duas teses nas diferentes áreas do conhecimento. Dessas duas teses por área, uma seria mais antiga, representativa da velha guarda de professores, inclusive dos já aposentados. E a outra seria de um professor mais jovem, representativa das novas gerações docentes. Na área de ciências sociais, a tese representativa das velhas gerações foi Os parceiros do Rio Bonito, de Antonio Cândido. A surpresa foi a indicação de Eficácia jurídica e violência simbólica como a tese representativa do padrão USP nas novas gerações. Ou seja, justamente uma tese cujo autor não havia sido indicado, meses antes, para a titularidade do Departamento de Filosofia e Teoria Geral do Direito. Do ponto de vista político, foi a resposta da instituição por iniciativa de vários professores da velha guarda de diferentes áreas da Faculdade de Filosofia - ao que havia ocorrido no concurso do qual participei. Do ponto de vista estético, o livro foi bem produzido editorialmente, com uma capa maravilhosa. Ganhou resenhas elogiosas na imprensa e a edição se esgotou em muito pouco tempo.

\section{A AFIRMAÇÃO DO CAMPO DA SOCIOLOGIA JURÍDICA}

De alguma forma, repetiu-se comigo o que estava ocorrendo com outros professores de Sociologia Jurídica, uma matéria que, por seu potencial crítico, jamais foi bem vista pelos dogmáticos. É curioso que Caio Tácito tenha agido pelo menos duas vezes nessa linha destrutiva, fechando o CEPED e prejudicando o Joaquim, no Rio, e travando minha careira, aqui em São Paulo - e isso com apoio do então jovem líder da oxigenação do ensino jurídico. A trajetória da disciplina de Sociologia Jurídica nunca foi fácil. Quando fui convidado para integrar a Comissão de Reforma do Ensino Superior, em 1985, disseram-me que os demais membros eram professores comprometidos com a qualidade e com a isenção. Ao chegar em Brasília, sabem que encontrei presidindo a comissão? Ele mesmo, o próprio, o presidente do Conselho Federal de Educação, Caio Tácito. Imaginava manipular todos, como era de seu feitio. Mas não conseguiu por causa do surgimento de um grupo integrado pelo Giannotti, pelo Simon Schwartzmann, pelo Carlos Nelson 
Coutinho, pelo Bolívar Lamounier e por mim. Éramos minoritários, mas os majoritários primavam pelo absenteísmo, o que nos levava a ganhar algumas votações importantes.

Como era inevitável, sempre que podia Caio Tácito lançava farpas contra sociólogos do direito. Dizia que a sociologia do direito não tinha autarquia epistemológica. Juntamente com outros juristas conservadores da turma do Reale vinculados ao Conselho Federal de Cultura, também afirmava que a sociologia do direito era uma variante pobre do realismo jurídico, sem densidade sociológica o suficiente para se constituir em disciplina independente. O que prevalecia era a filosofia do direito de um lado, e a tradição, de outro. A sociologia se misturava e se confundia com a questão do realismo jurídico. Muito mais sofisticado do que Caio Tácito, Reale não gostou dos relatórios do CNPq e da Capes, não gostou da pressão das duas agências para a criação de uma disciplina de Sociologia Jurídica e para tentar tirar os cursos de direito do marasmo, mas agiu com maior pertinência. Ele percebeu duas coisas com uma certa clareza: primeiro, que as avaliações da CAPES e do CNPq não tinham tanta força perante as faculdades de direito. Universidades públicas mais tradicionais, como a USP, não davam tanta importância para as avaliações, pois até então não havia uma cultura de avaliação, não havia uma cultura de ranqueamento, não havia Qualis. Era tudo muito incipiente. Em seguida, quando tomou consciência de que era inexorável a determinação das autoridades educacionais para a criação da disciplina de Sociologia Jurídica, agiu com habilidade política. Defendeu que o curso tivesse apenas um semestre, ficando como uma espécie de continuidade de Introdução ao Direito e antessala da disciplina dele, Filosofia do Direito. O pequeno grupo que se propunha a assumir as aulas dessa disciplina, integrado pelo Joaquim, pelo Luciano [de Oliveira], pelo [Roberto] Lyra Filho, pelo Zé Geraldo [de Sousa Jr], pelo Warat e por mim, reagiu de imediato, enfatizando a Sociologia do Direito como disciplina independente, responsável pela conexão entre o jurídico e social, com forte preocupação interdisciplinar. Afirmando que ela não tinha como se interessar pela validez formal das 
leis sem levar as condições sociais para sua efetividade, dizendo que uma ciência existe quando há um sistema de conhecimentos coerentes, obtidos com métodos rigorosos, acerca de determinados objetos e mostrando como a análise jus-sociológica podia abrir caminho para reflexões consistentes cada vez mais críticas ao formalismo e ao positivismo jurídico. De algum modo, a estratégia dos velhos catedráticos vinculados aos Conselhos Federais de Educação e Cultura foi tentar ensanduichar Sociologia do Direito, para que ela não vicejasse. Nas reuniões da Comissão de Ensino Superior, assim, acabei revivendo o que, de certo modo, já havia vivenciado na Capes e no CNPq.

Naquelas reuniões, principalmente as do CNPq, Joaquim e eu começamos a perceber tentativas de se colocar pessoas de outras áreas para lecionar Sociologia Jurídica. Percebemos, também, que outros professores de gerações posteriores à nossa, e que trabalhavam na área, como João Maurício Adeodato e Luciano de Oliveira, em Recife, Gisele Citadino e Eliane Junqueira, no Rio, e Celso Campilongo, em São Paulo, não tiveram vida fácil quando começaram a lecionar a disciplina. As chamadas "guerras palacianas" eram pesadas e acirradas. Portanto, conquistado um espaço para a Sociologia Jurídica, tornada disciplina obrigatória no começo dos anos 1980, o grande desafio era mantê-lo. E, para tanto, foi decisiva a criação, na Anpocs, do Grupo de Trabalho Direito e Sociedade. Graças à Gisele e Eliane, houve um período em que eu fui o coordenador desse grupo. Tive também apoio do pessoal da UnB, liderado pelo Roberto Lyra e pelo José Geraldo de Souza Júnior, que mais tarde seria reitor da instituição. Tanto o GT quanto meu trabalho na USP deram-me muita visibilidade, o que resultou em convites para aulas e palestras por todo o país. Acho que só não falei em Roraima, Amapá, Acre e Rio Grande do Norte.

Há acontecimentos interessantes nesse período pré e pós Comissão de Ensino Superior. Um deles foi a visita ao trabalho de campo do Joaquim em 1980, sobre ocupações de propriedades urbanas em Recife. Juntamente com o Henry Steiner, de Harvard, e com Boaventura, ficamos hospedados em Olinda na casa do Aloisio Magalhães, o secretário da cultura da época. Joaquim e Aloisio eram vizinhos numa ladeira que, se não 
me falha a memória, é a Ladeira da Misericórdia. Tiramos uma foto, no muro das duas casas, em que estão o Boaventura, o Joaquim e eu. A foto foi tirada pelo Steiner, de Harvard, e por uma brilhante assistente do Joaquim naquele momento, Alexandrina Moura. Ficamos dias entre Olinda e Recife, acompanhando as pesquisas da favela do Skylab, resultante de uma ocupação. De tanto conversarmos com Boaventura, principalmente, chegamos a conclusão de que, se quiséssemos sobreviver na sociologia jurídica, não tínhamos alternativa a não ser expandir a área de sociologia, buscando mais formação na área. Havia uma tendência dos sociólogos olharem para nós, sociólogos do direito, e alegar que nós não entendíamos de sociologia. Já os professores de filosofia do direito olhavam para nós, dizendo que nós podíamos até entender de filosofia e sociologia, mas nós não entendíamos de direito. Era preciso acabar com aquilo.

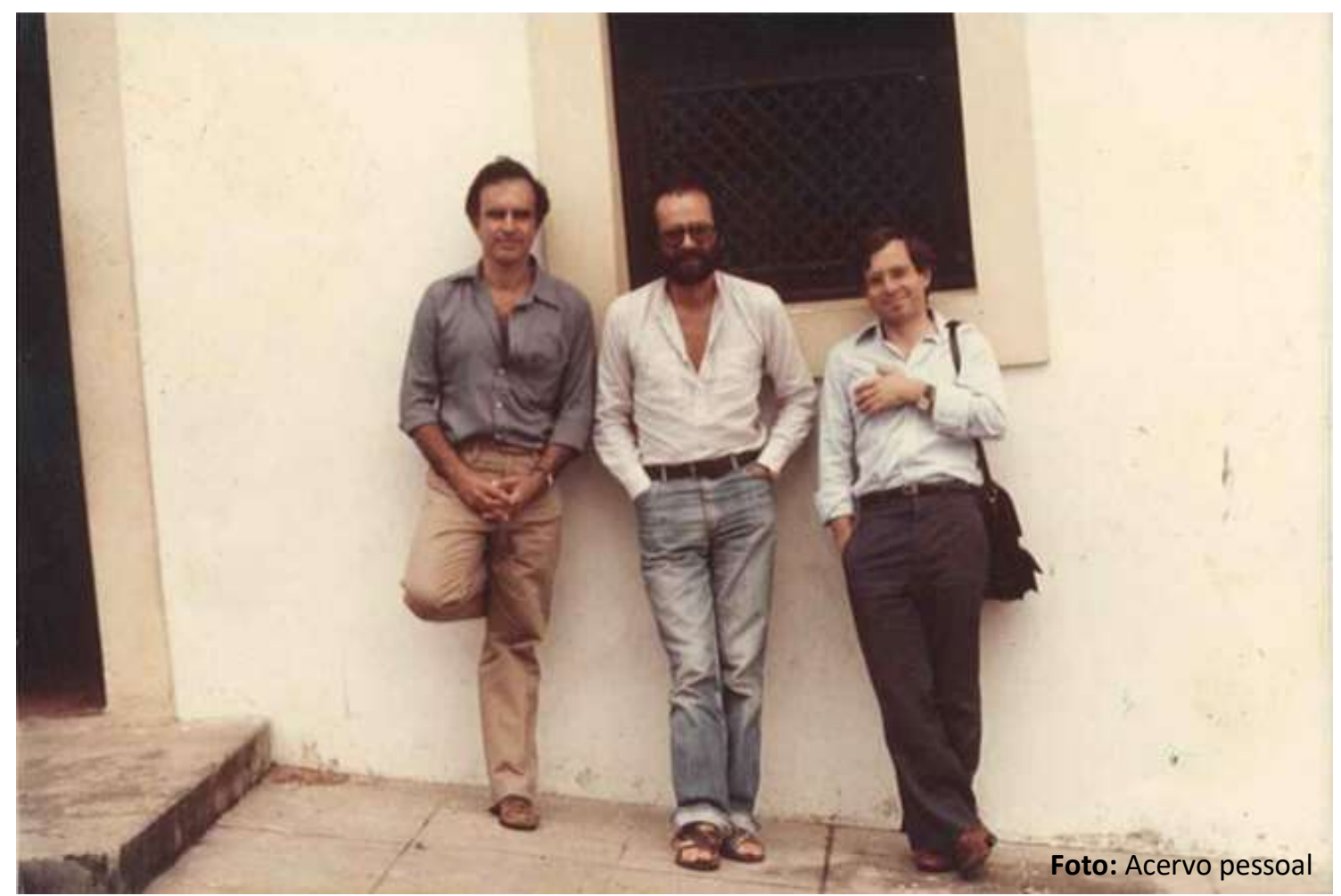

Para mim, aquela fotografia tornou-se um ícone. No meu caso, esse foi um dos motivos que me levou primeiramente a trabalhar com o David Trubek, em 1983 na 
Wisconsin Law School, e mais tarde a passar em diferentes oportunidades pelo Centro de Estudos Sociais da Universidade de Coimbra, sempre acolhido com generosidade pelo Boaventura, pela Maria Manuel, pelo Leitão Marques, pelo [Antônio] Casemiro [Ferreira] e pelo João [António Fernandes] Pedroso. E, por fim, a passar pelo menos uma vez por ano, durante toda a década de 1990, no International Institute for Sociology of Law, em Oñati, no País Basco.

Há um trabalho interessante feito por uma dupla muito respeitada de sociólogos, o francês Yves Dezalay e o americano Bryant Garth, que é o chefe do departamento de pesquisa do American Bar Association. Quando fizeram um trabalho sobre guerras palacianas, as disputas entre escolas de direito e outras escolas, eles também tentaram identificar, no caso brasileiro, os juristas que faziam a opinião pública dos meios forenses e as opiniões jurídicas em geral. Para a minha surpresa, apareceu meu nome. Eu que nunca advoguei nem frequentei tribunais. Um dia, o Bryant Garth me diz o seguinte: "olha, caiu a ficha. Desta lista de 20 ou 25 nomes, tem uns quatro ou cinco que não advogam. E, curiosamente, todos eles passaram por Madison". Ou seja, pelas mãos competentes do Trubek. Num seminário em Madri, fui tomar um café com o Dezalay na cafeteria da Complutense e ele disse a mesma coisa: "todos aqueles que fazem o pensamento jurídico no Brasil e também na Colômbia, com um viés mais crítico, passaram pela mão do Trubek, todos passaram por Madison." Ele destacou a atuação do Instituto Latinoamericano para una Sociedad y un derecho Alternativos (ILSA), coordenado pelo [Maurício García] Villegas e pelo [César] Rodríguez, que também passaram por Madison.

Voltando um pouco atrás, em 1987, o Carlos Guilherme Motta e eu montamos um projeto para fortalecer, na área de ciências humanas, o diálogo entre a história e direito. Além do próprio Boaventura, que passou quatro meses conosco aqui em São Paulo, trouxemos em seguida o Raymundo Faoro. As aulas de Boaventura na Faculdade de Direito eram imperdíveis. As salas ficaram tão lotadas que, por falta de espaço, foram transferidas para as dependências do Conselho Universitário da USP. E, para tanto, contei com apoio da 
minha primeira geração de mestrandos e doutorandos, integrada por Celso Campilongo, José Reinaldo de Lima Lopes, Maria Cecília MacDowell dos Santos, Taís Gasparian e Antonio Benedito Margarido, e por uma orientanda de iniciação científica que fazia direito e ciências sociais simultaneamente, a Ana Lúcia Pastore Schritzmeyer. Foi esse o grupo que criou o Centro de Estudos Direito e Sociedade (Cediso), na USP. Ele surgiu da necessidade de fazer pesquisa empírica. Definimos um projeto sobre assessoria jurídica popular tradicional ou inovadora, em São Bernardo, e fomos crescendo, o que nos deu visibilidade e uma sucessão de convites para falar dar conferências pelo Brasil afora. Desenvolvemos programas de qualificação de escolas de magistratura, associações de juízes e associações de promotores. Trabalhamos com temas como ampliação do acesso aos tribunais, judicialização da política, constitucionalização e restabelecimento da legalidade. Além, é claro, de muita discussão sobre hermenêutica, aplicação das leis e eficácia jurídica. O trabalho era pesado, mas fascinante. Olhando para trás, não sei se o Celso [Campilongo] concorda comigo, ajudamos na formação de lideranças corporativas e ativistas políticos que também eram professores de direito. E alguns chegaram aos tribunais superiores, inclusive ao Supremo. Um dos frutos dessa experiência é um trabalho do próprio o Celso sobre advocacia inovadora e advocacia tradicional do direito ${ }^{11}$.

Foi aí, justamente quando fui indicado para integrar o Instituto de Estudos Brasileiros da USP, que surgiu o convite para dar aula de sociologia jurídica no recém criado curso de direito da Universidade São Judas Tadeu. Em princípio, não queria aceitar as duas novas tarefas porque estava numa fase em que o banco me demandava muito e a São Francisco, também. Mas chegou uma hora em que eu olhei para todo o meu pessoal e me perguntei: o que faço com esse bando de gente que estou formando na pós? Esse pessoal vai conseguir entrar na Faculdade de Direito da USP? Em que medida a velha

\footnotetext{
${ }^{11}$ CAMPILONGO, Celso Fernandes. Assistência Jurídica e Advocacia Popular: Serviços Legais em São Bernardo do Campo. Revista da Procuradoria Geral do Estado de São Paulo, v. 41, 1994.
} 
guarda do departamento não vai bater neles para me alcançar, como já havia ocorrido com o Celso e com o Zé Reinaldo? Fazia sentido desprezar os dois convites? Então negociei com a São Judas: "venho dar sociologia jurídica desde que vocês me deixem montar a área de teoria, sociologia e filosofia do direito". Era tudo o que eles queriam. O resultado disso é que levei para lá uma geração de orientandos, integrada por Marta [Rodriguez de Assis Machado], Maíra [Rocha Machado], Jean-Paul [Rocha], Diogo [Coutinho], Paulo Mattos, a própria Cecília MacDowell... Levei, também, o Fernando [Herren Aguillar], e o Floriano [de Azevedo Marques Neto], que acaba de ser eleito diretor do Largo São Francisco. Devo ter levado uns quinze professores para lá, talvez mais. Todos os professores que convidei para a São Judas passaram pelo PET. A experiência deu tão certo que, algum tempo depois, dela me vali para elaborar o projeto de um curso de direito para a Unicamp. A instituição não tinha esse curso e o conselho universitário indicou três docentes para que o reitor escolhesse apenas um para fazer o projeto. Os nomes eram: Comparato, Mangabeira Unger e eu. Foi um trabalho intenso, mas que resultou em nada. Os representantes de alguns cursos no conselho universitário fizeram duas objeções. Tinham medo de que o curso de direito sugasse o orçamento dos demais cursos já existentes. E tinham receio de que os professores de direito passassem a intervir demais nas reuniões do conselho universitário, invocando a expertise jurídica. Foi uma discussão curiosa, bem corporativa. E muitos dos que resistiram à criação do curso de direito na Unicamp me procuraram depois, para se justificar educadamente.

Esse foi um momento foi de lamber as feridas, de tentar renascer das cinzas após o concurso na USP. No tempo em que atuou, o Cediso fez trabalhos importantes. A partir daquele momento, Celso ganhou, em 1992, o prêmio da USP de melhor tese de pósgraduação e eu o prêmio de melhor orientador na área de ciências humanas. Em seguida, passei a integrar o corpo editorial do International Institute for Sociology of Law e, mais tarde, fui convidado por Joaquim Herrera Flores para dar uma disciplina na Universidade Internacional de Andaluzia, em Huelva, e, em seguida, na Universidade Pablo de Olavide, 
em Sevilha, na Espanha. E, por indicação do Celso, que tinha ido estudar com o Raffaelle di Giorgi, em Lecce, passei dois períodos de cerca de um mês, entre 1995 e 1996, lecionando na Università degli Studi del Salento, na Itália.

Neste período, havia a necessidade de reformular o mestrado e o doutorado da Faculdade de Direito. Deu trabalho porque havia muita resistência a qualquer mudança. A mais importante delas foi com relação ao exame de qualificação, que era uma prova escrita redundante e inócua, com base em dez pontos divulgados com um mês de antecedência. Eu a substitui por uma avaliação, feita por três professores de dentro e de fora da faculdade, dos projetos de dissertação de mestrado e doutorado. A ideia era transformar a avalição numa espécie de controle de qualidade e num apoio ao orientador. A ideia também era, por um lado, envolver mais os alunos da pós em discussões sobre metodologia científica e teoria jurídica, política e social. E, por outro, acabar com a tradição de citações prolíficas e de longas introduções generalistas e históricas que então prevalecia no Largo São Francisco. Hoje, vinte anos depois, vejo que a adoção desse tipo de avaliação, que vi em várias universidades americanas e europeias, deu certo. O fato é que, com base na experiência acumulada na época do Cediso, na chefia da pós-graduação da USP, na Comissão de Ensino Superior, nas agências de fomento à pesquisa e nas passagens por Madison, Coimbra, Oñati e Lecce, percebi que havia adquirido mais prestígio e autoridade do que imaginava. Também percebi que estava no caminho certo para disputar um segundo concurso para titular.

\section{2 “CAMINHO CERTO”}

Defendi a segunda tese em fevereiro 1998. Portanto, foi um hiato de 14 anos entre a primeira e a segunda oportunidade. Assim que essa vaga foi aberta, disseram-me que o próprio Tércio tentaria patrocinar dois candidatos para concorrer comigo. Se é verdade, não sei. Mas o fato é que o concurso poderia ter sido realizado em 1996, não fosse a 
tentativa de um desses candidatos de disputar sem ter o título de livre-docência e querendo registro com base no princípio de notório saber, uma coisa assim. Esse candidato passou a ingressar com dezenas de recursos na Congregação. Foi uma espera de dois anos. E, mesmo quando ganhei, ele recorreu para impedir que eu tomasse posse e para que o concurso fosse anulado. Ele foi perdendo em todas as instâncias, inclusive no Supremo. Por isso, minha posse só se deu anos após o término do concurso.

Nesse meio tempo, um dia o Ary Oswaldo [Mattos Filho] me convida para tomar um café e pergunta se eu queria ou não trabalhar com ele num projeto da Fundação Getúlio Vargas. Como não quis, ele me ofereceu o cargo de auxiliar de diretor. Também não pude aceitar porque o Olavo Setúbal pedia que ficasse mais tempo no banco. Minha sugestão foi a mesma dada ao pessoal da São Judas. Disse ao Ary: "a única possibilidade de vocês crescerem é com jovens doutores, com uma formação interdisciplinar". Em seguida, enviei os currículos de antigos alunos com formação impecável, como Diogo Coutinho, Paulo Mattos, Jean Paul Cabral Veiga da Rocha, Emerson Fabiani, Maíra Rocha Machado, Marta Rodriguez Machado, Michelle Ratton Sanches, Camila Duran e Denise Ramos Vitale. Por seu lado, o próprio Ary já havia chegado a esses nomes, antes de minha indicação. O pessoal foi aceito, mas deixou um vácuo na Universidade São Judas. Que aproveitei, é claro, para montar mais uma equipe por lá, mantendo meus novos orientandos unidos num espaço acadêmico. Desde que passei a lecionar na pós-graduação, por volta de 1983, privilegiei a qualificação de meus orientandos. Dei vez a quem tinha - e tem sensibilidade para ciência política, sólida formação em filosofia, sólida formação sociológica, especialmente a partir de Marx e Weber. E eles se destacaram nas duas oportunidades, tanto na São Judas quanto na FGV. Com isso, os que optaram pela carreira acadêmica, entre as diferentes gerações de orientandos que tive em mais de 40 anos de docência, acabaram formando uma malha de relacionamentos com as mais variadas universidades americanas, como Yale, Stanford, Columbia, Berkeley, Harvard e Wisconsin, e europeias, como a London School e a Warwick, na Inglaterra, o Instituto Max Planck, na 
Alemanha, a Universidade de Paris I e a Universidade Jean Monet, na França, a Università del Salento e o European International Institute, na Itália, as Universidades de Barcelona e Carlos III, na Espanha.

Pela paciência com que ouviram as respostas, acho que isso é suficiente para descrever minha carreira. Consegui extrair da redação de um jornal o que um professor precisa: informações, contatos e espaço público para projetar discussões. Da universidade, extraí base teórica, conhecimento, conceito, rigor, grade conceitual, visão de mundo. E, do banco, extraí visão sistêmica do ponto de vista institucional, preparo para gestão e capacidade de entender o funcionamento das máquinas administrativas do mundo universitário, o que me levou, acho eu, a chefiar um departamento sem gerar tensões, por um lado, e com forte apoio de todos os docentes, por outro. Acima de tudo, a soma dessas experiências lapidou o que sempre quis ser: professor. 